\title{
Reproductive performance, biochemical composition and fatty acid profile of wild-caught and 2nd generation domesticated Farfantepenaeus duorarum (Burkenroad, 1939) broodstock
}

\author{
Maurício Emerenciano ${ }^{a, b, ~}{ }^{*}$, Gerard Cuzon ${ }^{c}$, Maite Mascarób ${ }^{b}$ Miguel Arévalo ${ }^{b}$, Elsa Noreña-Barroso ${ }^{d}$, \\ Gilberto Jerónimo ${ }^{\mathrm{b}, 1}$, llie S. Racotta ${ }^{\mathrm{e}}$, Gabriela Gaxiola $^{\mathrm{b}}$ \\ a Posgrado en Ciencias del Mar y Limnología, Universidad Nacional Autónoma de México (UNAM), Mexico \\ b Unidad Multidisciplinaria de Docencia e Investigación, Facultad de Ciencias, UNAM, Sisal, Yucatán, Mexico \\ c Ifremer BP7004 Taravao, Tahiti, French Polynesia \\ d Unidad Multidisciplinaria de Docencia e Investigación, Facultad de Química, UNAM, Sisal, Yucatán, Mexico \\ e Programa de Acuicultura, Centro de Investigaciones Biológicas del Noroeste S.C., La Paz, B.C.S., Mexico \\ ${ }^{1}$ In memoriam
}

*: Corresponding author : Maurício Emerenciano, Tel.: + 554896800311 ;

email address : mauricioemerenciano@hotmail.com

\begin{abstract}
:
A 30-day trial was performed to evaluate the reproductive performance of wild and 2 nd generation domesticated Farfantepenaeus duorarum broodstock. Changes in biochemical composition and fatty acids (FA) profile in the 1st and 4th spawn order females were used as indicators of nutritional condition. Wild population of $F$. duorarum presented significantly better reproductive outcomes as compared to domesticated ones. Wild spawners achieved significantly higher number of eggs per spawn, number of egg per spawn per $\mathrm{g}$ of spawner's body weight and number of nauplii per spawn $(P<0.05)$. Latency period was significantly shorter $(P 0.05)$ for wild than for domesticated females (11 vs 17 days). Wild spawners also presented less mortality (6 vs 12\%), higher number of total spawns (51 vs 33), spawns per ablated and per spawning females as well as higher total eggs and nauplii production. On the other hand, domesticated females presented higher number of females that spawned at least once ( 89 vs $76 \%$ ). The higher spawning activity was reflected in lower levels of acylglycerides (AG) and cholesterol content in wild hepatopancreas (HP) and ovary (OV) (Pb0.05). FA profile, mainly represented by ARA, EPA and sum of $n-3$ were higher in hepatopancreas and ovary of wild females, however lower levels were detected in eggs as a result of a high spawning activity. Multivariate analysis performed to detected simultaneous variation in biochemical variables indicated $A G$ as variation pattern's responsive.
\end{abstract}

\section{Highlights}

Original paper comparing the reproductive performance of wild and G2 F. duorarum. Interesting findings using biochemical composition/FA profile as a nutritional index. Multivariate analysis method contributed to explain the results. Wild population performed better reproductive performance.

Keywords: Fatty acids ; F. duorarum ; Lipids ; Pink shrimp ; Nutrition ; Reproduction 
Penaeid shrimp is a valuable ecological and economic resource, but the majority of its production, research and development efforts have been directed to only a few candidate species. Since current hatcheries predominantly focus on Litopenaeus vannamei and Penaeus monodon, the two most studied species, availability of other penaeid larvae and postlarvae are limited, depending mostly upon wild stocks. In addition, a variety of indigenous shrimp species, valuable for aquaculture as a source of possible virus-free and virus-resistant stocks, may present higher growth rates under specific environmental conditions, as well as better acceptance in local markets (Peixoto et al., 2011).

The pink shrimp Farfantepenaeus duorarum is naturally distributed in the western Atlantic Ocean from Maryland (EUA), through Gulf of Mexico until Ascensión Bay in Quintana Roo, Mexico (Pérez-Farfante, 1969). In recent years the relative importance of cultivating $F$. duorarum has increased due to signs of depletion in thewild fishery, inwhichwas a very important resource in southern Gulf of Mexico, but is currently collapsed (Arreguin-Sanchez et al., 2008). High yields were obtained during the early 70 s, with approximately 27,000 t per year, of which $90 \%$ was $F$. duorarum, however yields dropped below $3000 \mathrm{t}$ per year (Arreguin-Sanchez et al., 2008). Hypotheses suggested that this collapse is essentially represented by pollution in nursery areas (Arreguín-Sánchez et al., 1997); estuary and offshore over-fishing (Gracia, 1995, 1997).

Previous studies have been considered $F$. duorarum for shrimp farming (Cripe, 1994; Gullian et al., 2010; Samocha et al., 2008)mainly focused on the localmarket value (López-Téllez et al., 2000). However, high costs associated with the capture of the wild stocks remain unsolved (Menasveta et al., 1993). To overcome this problem, research efforts have been performed in many penaeid species comparing wild vs domesticated stocks and evaluating several characteristics of reproductive 
performance and spawn quality such as zootechnical parameters (Cavalli et al., 1997; Coman et al., 2006; Keys and Crocos, 2006; Menasveta et al., 1993; Palacios et al., 1999a), indicators of nutritional condition of broodstock, based on biochemical composition of hepatopancreas, hemolymph and/or ovary (Marsden et al., 2007; Nakayama et al., 2008; Palacios et al., 2000; Peixoto et al., 2008) or biochemical composition of eggs and nauplii as indicators of spawn quality (Palacios et al., 1998, 1999b; Regunathan, 2008). On the other hand, no studies had integrated all these approaches in the same work, clarifying the whole metabolic pathway of nutrients from food stored in hepatopancreas (HP), transported through the hemolymph to ovaries (OV), and then transferred to eggs and metabolized during their development to nauplii; as well as the associated reproductive performance and spawn quality.

Understanding the effect of different food sources on reproductive output will enable broodstock performance to be improved. Differences in food items ingested prior to ablation in wild such as benthos, rotifers, copepods, polychaetes, bivalves and other small crustaceans (Schwamborn and Criales, 2000; Soares et al., 2004, 2005); or in captivity such as pelleted feed, squid and mussels (Browdy, 1998; Cavalli et al., 1997; Marsden et al., 1992; Peixoto et al., 2008) may often give the broodstock an adequate nutrition. However, limitation in certain dietary nutrients occurs due to a seasonal and storage factors (Bray and Lawrence, 1992; Wouters et al., 2001a).

Spawning frequency is often used as an index of reproductive performance which is turn based on multiple spawning capacities that could be a desirable trait (Ibarra et al., 1997). However, it could also involve a decrease in spawn quality over consecutive spawns (Emmerson, 1980; Hansford and Marsden, 1995; Wouters et al., 1999), although this is not necessarily the case (Arcos et al., 2005a; Browdy and Samocha, 1985; Palacios and Racotta, 2003). So, rather than evaluating the spawning frequency itself, the analysis of the potential effect of spawn quality over consecutive spawns could be a useful tool to select the best condition or diet for optimal reproductive performance (Coman and Crocos, 2003; Marsden et al., 1997; Palacios et al., 1999a). Biochemical composition has been used as a tool to compare the physiological and immunological condition of $F$. duorarum wild population (Rosas et al., 2007), but few studies focused on broodstock and its relation with multiple spawns. Thus, the aim of this study is to evaluate the reproductive performance of wild-caught and domesticated $F$. duorarum broodstock using biochemical composition and FA profile as indicators of shrimp nutritional condition.

\section{Materials and methods}

\subsection{Wild-caught broodstock}

Wild adult $F$. duorarum were captured by bottom otter trawl in 15-25 m deep waters, off the coast of Campeche ( $19^{\circ} 50^{\prime} \mathrm{N} / 91^{\circ} 30^{\prime}$ $\mathrm{W})$, Mexico. Animals were transported to the laboratory, selected based on body morphological integrity and acclimated for 1 week before the start of experiment.

\subsection{Domesticated broodstock}

Second generation tank-reared domesticated $F$. duorarum broodstock were raised at Unidad Multidiciplinaria de Docencia e Investigación (UMDI), Universidad Nacional Autónoma de México (UNAM), located at Sisal Beach $\left(21^{\circ} 09^{\prime} 5 / \mathrm{N}\right.$ and $\left.90^{\circ} 02^{\prime} 5 / \mathrm{W}\right)$, Yucatán, Mexico. The two-stage culture system consisted of indoor $400 \mathrm{~L}$ larviculture tanks (nursery: until PL 20 stage) and 20,000 L round lined outdoor tanks covered by shade cloth, where PL were later transferred (growout tanks). The grow-out tank-reared culture system (20,000 L circular lined tanks; $1 \mathrm{~m}$ deep) consisted of water exchange about 25\% per day and animals were fed ad libitum twice a day (09:00 and 17:00 h) with $35 \%$ crude protein dry pellets (Malta Clayton, Inc., Culiacan, Sinaloa,
Mexico) during 15 months. Temperature, salinity, $\mathrm{pH}$ and dissolved oxygen (Hach HQ40d, Hach Company, Loveland, Colorado, USA) were monitored daily at $09: 00 \mathrm{~h}$ and varied between $17-32^{\circ} \mathrm{C}, 33-42 \mathrm{ppt}$, 7.4-8.5, and 3.9-6.9 $\mathrm{mg} \mathrm{L}^{-1}$, respectively. Animals were transported to the maturation room and selected followed by wild breeders.

\subsection{Experimental design}

During 30 days, reproductive performance trial was performed using four $12,000 \mathrm{~L}$ round lined maturation tank with recirculation system maintaining temperature stable $\left(28 \pm 1^{\circ} \mathrm{C}\right)$. In each tank, groups of 17 females and 35 males from each source were stocked (female to male ratio $1: 2$ and stocking density of 4.3 shrimp $\mathrm{m}^{-2}$ ). Two tanks were used to collect samples for biochemistry and FA and another two were used for trials on reproductive performance. Each female was considered an experimental unit (Nakayama et al., 2008). Animals were fed ad libitum three times per day (09:00, 01:00 and 20:00 h) alternating frozen squid, mussels, Artemia biomass and polychaetes.

\subsection{Reproductive performance}

Before the start of the trial, each female was weighed, unilaterally eyestalk ablated and tagged using silicon eye rings. Females with mature ovaries (ready-to-spawn) were identified daily at 18:00 h and transferred into separated $100 \mathrm{~L}$ circular tanks located in a temperature controlled spawning room $\left(28-29^{\circ} \mathrm{C}\right)$. Gentle aeration was supplied to each tank. The number of eggs and nauplii was estimated from five $4.7 \mathrm{~mL}$ replicate samples taken in spawning tanks, collected after gentle swirling. Fertilized and hatch rates of viable spawning were determined (Primavera and Posadas, 1981). Reproductive performance was evaluated in terms of latency period (interval between eyestalk ablation and first spawn), females that spawn at least once (\%), mortality (\%), total spawns, unfertilized spawns, number of spawns per ablated females, number of spawns per spawning female, maximum spawn order, number of egg and nauplii per spawn, fertilization and hatching rate. Larval body length and weight from first spawns of different origins were also measured in stages of zoea, mysis and $\mathrm{PL}_{\mathrm{I}}$.

\subsection{Samples collection}

HP and OV were collected from wild and domesticated ripe females in the 1st and 4th spawn order. HP and OV were removed through an incision on the back of the cephalothorax and dorsal region of the entire abdomen length, respectively. The samples were weighed, placed in a $1.5 \mathrm{~mL}$ Eppendorf tube, immediately frozen in liquid nitrogen and preserved at $-80^{\circ} \mathrm{C}$ for further biochemical and FA analysis. Hepatosomatic index (HSI) and gonadosomatic index (GSI) were calculated as a percentage of the hepatopancreas and ovarian weight, respectively, relative to the body weight.

Hemolymph (100 $\mu \mathrm{L})$ was sampled according to Pascual et al. (2003) to assess hemocyanin and biochemical composition. Eggs and nauplii were collected directly from spawning and hatching tanks, respectively. The samples were carefully dried with a scarf paper, weighed, placed in a $1.5 \mathrm{~mL}$ Eppendorf tube, immediately frozen in liquid nitrogen and also preserved at $-80^{\circ} \mathrm{C}$ for further analysis. Number of samples collected (according availability of spawns over time) for domesticated 1st and 4th spawns and wild 1st and 4th spawns were: HP, hemolymph and OV: 6, 6, 5 and 3; eggs and nauplii: 6, 6, 9 and 6, respectively.

\subsection{Biochemical composition}

Changes in metabolite levels of wild and domesticated broodstock at different spawn order (1st and 4th) were performed in hemolymph (acylglycerides "AG", cholesterol, glucose and total soluble proteins "TSP") and in HP, OV, eggs and nauplii (AG, cholesterol and 
TSP). The indices including acylglycerides/total soluble protein (AG: TSP) and acylglycerides/cholesterol (AG:C) were calculated in HP, $\mathrm{OV}$, eggs and nauplii using the metabolite data following specification given by Mourente and Rodríguez (1997) and Palacios et al. (1998).

$\mathrm{HP}, \mathrm{OV}$, eggs and nauplii were homogenized in $500 \mathrm{ml}$ of distilled water for $2 \mathrm{~min}$. Aliquots of $10 \mu \mathrm{L}$ were taken to determine $\mathrm{AG}$ and cholesterol with $200 \mu \mathrm{L}$ of reactive solution (kits ELITech TGML0427 and ELITech CHSL-0507, respectively; ELITech Group, Puteaux, France). The remaining sample was centrifuged at $800 \mathrm{~g}$ for $20 \mathrm{~min}$ at $4{ }^{\circ} \mathrm{C}$, and $10 \mu \mathrm{L}$ of the supernatant was collected in Eppendorf tubes to determine TSP with $200 \mu \mathrm{L}$ of reactive solution (Bradford, 1976). Solutions were placed in microplates and incubated in an oven for 7, 5 and $5 \mathrm{~min}$ in 37,37 and $24^{\circ} \mathrm{C}$ for $\mathrm{AG}$, cholesterol and TSP, respectively. Immediately, samples were read in an ELISA lector (Biorad 550, Bio-Rad Inc., Richmond, CA, USA) at $500 \mathrm{~nm}$ of absorbance length for AG and cholesterol; and $595 \mathrm{~nm}$ for total protein. A blank was considered with distilled water and the final concentrations $\left(\mu \mathrm{g} \mathrm{g}^{-1}\right.$ ) were calculated from a calibration curve, in which the standard was the substrate that acts as the reagent in the kit.

To obtain metabolite concentrations in hemolymph, it was extracted and diluted using anticoagulant solution (Vargas-Albores et al., 1993) considering a hemolymph-anticoagulant ratio equal to $1: 2$. The hemolymph plus anticoagulant was centrifuged at $800 \mathrm{~g}$ for 3 min at $4{ }^{\circ} \mathrm{C}$ and the supernatant was collected in Eppendorf tubes. Glucose (kit ELITech GPSL-5505, ELITech Group, Puteaux, France), cholesterol, AG and TSP (Bradford, 1976) determinations were made in aliquots of $10 \mu \mathrm{L}$ with $200 \mu \mathrm{L}$ of reactive solution. Samples were immediately placed in microplates, incubated and read in an ELISA lector. Anticoagulant solution was used as a blank. Same incubation time, absorbance length and calculations of final concentration ( $\mu \mathrm{g} \mathrm{mL}{ }^{-1}$ ) were made as described above, except by glucose with 2 min of incubation time in $37^{\circ} \mathrm{C}$ at $500 \mathrm{~nm}$ of absorbance length.

For hemocyanin measurements, $10 \mu \mathrm{L}$ of hemolymph was immediately diluted in $990 \mu \mathrm{L}$ of distilled water in a $10 \mathrm{~mm}$ cuvette for UVwavelength spectroscopy $(1.0 \mathrm{~mL} ; 1 \mathrm{~cm}$ path length), and the absorbance was measured at $335 \mathrm{~nm}$. The final concentration $\left(\mathrm{mmol} \mathrm{L}^{-1}\right)$ was determined according to Chen and Cheng (1993) using the coefficient of extinction of hemocyanin (17.26) and factor of dilution (1:100).

\subsection{Fatty acid profile}

The FA profile of 1st and 4th spawn order (HP and OV samples) and 1st to 4th spawn order (eggs samples) were measured in wild and domesticated populations. Pooled samples were maintained at $-80^{\circ} \mathrm{C}$ and then freeze-dried prior to analysis. Number of organisms or spawns per pooled sample is given in Section 2.5, except by eggs from 1st to 4th in both domesticated and wild with 9, 6, 6 and 6 spawns per pooled sample, respectively. Samples were homogenized and 50 to $100 \mathrm{mg}$ subsamples were taken. Lipids were extracted with methylene chloride: methanol $(2: 1, \mathrm{v} / \mathrm{v})$ according to a modification of Folch extraction procedure (Folch et al., 1957). Lipid extracts were saponified with $20 \% \mathrm{KOH}$ :Methanol (w:v) and free FA were recovered in hexane from acidified saponifiable fraction $(\mathrm{pH}=1-2)$. FA methyl esters (FAME) were obtained by esterification with $10 \%$ $\mathrm{BF}_{3}$ in methanol (Fluka-Boron trifluoride-methanol solution, 15716, Sigma-Aldrich Co., St Louis, Missouri, USA) for $60 \mathrm{~min}$ at $80^{\circ} \mathrm{C}$. FAME were analyzed by capillary gas chromatography in a Perkin Elmer Clarus 500 GC (Perkin Elmer Inc., Shelton, Connecticut, USA) equipped with a Perkin Elmer Elite-WAX capillary column (30 $\mathrm{m} \times 0.25 \mathrm{~mm} \times 0.25 \mu \mathrm{m}$ film thickness, crossbond-PEG, Perkin Elmer Inc., Shelton, Connecticut, USA) and a flame ionization detector (FID). Hydrogen was used as carrier gas with a flow rate of $40 \mathrm{~mL} \mathrm{~min}^{-1}$. Injector and detector temperatures were programmed to $280^{\circ} \mathrm{C}$ and $250{ }^{\circ} \mathrm{C}$, respectively. Column temperature was programmed from 40 to $200{ }^{\circ} \mathrm{C}$ at $20^{\circ} \mathrm{C} \mathrm{min}^{-1}$ and from 200 to $250{ }^{\circ} \mathrm{C}$ at $2.5^{\circ} \mathrm{C} \mathrm{min}^{-1}$. FAME were identified by comparing retention times with reference standards (Supelco 37 Component FAME Mix, 47885-U and Fluka-Nonadecanoic acid, 72332, Sigma-Aldrich Co., St Louis, Missouri, USA) and results were reported as area percentages.

\subsection{Statistical analysis}

Two-way ANOVA followed by a Tukey test for unequal $N$ post-hoc mean comparisons were performed to assess significant differences in biochemical composition, HSI and GSI, using origin (O: wild and domesticated) and spawn order (S: first and fourth spawn order) as categorical factors in the model. For reproductive performance Student's t-test was applied to find the differences among the treatments when data were homogeneous and normality distributed (Zar, 1984). Percentage data were arcsin transformed, but only original values were presented. Differences were considered significant at $P<0.05$ (Sokal and Rohlf, 1995).

Multivariate analysis using Empirical Orthogonal Function "EOF" (Von Storch and Zwiers, 2001) was performed to detected simultaneous variation on biochemical parameters, determining the underlying patterns of temporal variation (1st and 4th spawn order) of AG, cholesterol and TSP performed in HP, OV, hemolymph, eggs and nauplii. Using Matlab 5.3 software (MathWorks Inc., Natick, MA, USA), the EOF analysis allowed us to identify not only the joint variation patterns, but we were also able to maximize the overall variance and capture the more energetic modes of variation (three in total), where "mode 1 " is the most energetic mode (for review, see Gomez-Valdes and Jeronimo, 2009). Furthermore, this analysis detected the variation pattern responsive described as the most energetic variable (MEV), expressed in $\%$ of the total mode 1 energy retention. EOF analysis were performed using $x_{n}=\frac{x-\bar{x}}{\sigma}$ transformed data where $x_{n}$ is the new data, with the aim to normalized variables with different scale (i.e. $\mathrm{mg} \mathrm{dL}^{-1}$ and $\mathrm{mg} \mathrm{g}^{-1}$ ). In addition, nutritional status pyramids were built using $\log _{10}+1$ transformed data from AG, cholesterol and TSP biochemical data from all tissues.

\section{Results}

\subsection{Reproductive performance}

Results of reproductive performance and morphometric parameters are given in Table 1 . Wild spawners achieved significantly better results $(\mathrm{P}<0.05)$ in terms of number of egg per spawn, number of egg per spawn per $\mathrm{g}$ of spawner's body weight and number of nauplii per spawn compared to domesticated spawners $\left(71.9,2.6\right.$ and $51.9 \times 10^{3}$ for wild spawners and $33.5,1.7$ and $25.6 \times 10^{3}$ for domesticated ones, respectively). Latency period was significantly shorter for wild than for domesticated females (11 vs 17 days). Wild spawners also presented less mortality ( 6 vs 12\%), higher number of total spawns ( 51 vs 33), spawns per ablated and per spawning females (3.0 and 3.9 for wild and 1.9 and 2.2 for domesticated, respectively) and achieved better total eggs and nauplii production (3306 and 2334 for wild and 1,071 and $487 \times 10^{3}$ for domesticated females). On the other hand, domesticated females presented higher number of females that spawned at least once (89 vs $76 \%$ ). Number of nauplii per spawn per $g$ of spawner's body weight, females weight, fertilization rate and hatch rate presented no significant differences between treatments $(P>0.05)$. Larval weight and length (zoea, mysis and postlarvae stage I) were significantly higher coming from wild compared to domesticated females $(\mathrm{P}<0.05)$.

Cumulative spawning given in Fig. 1 indicated that wild females started to spawn on the 3rd day, unlike domesticated ones that did on the 8th day and maintained a higher spawn rate until the end of the experiment. Number of eggs per spawn order and maximum spawn order is given in Fig. 2. Overall results showed that wild females increased the number of eggs per spawn over time whereas domesticated ones decreased their production. Wild females presented 
Table 1

Reproductive performance and morphometric parameters (means $\pm S D$ ) of domesticated (G2) and wild F. duorarum broodstock in a 30-d experimental period.

\begin{tabular}{|c|c|c|c|}
\hline & Domesticated & Wild & $\begin{array}{l}\text { Significance } \\
\text { level }\end{array}$ \\
\hline \multicolumn{4}{|l|}{ Reproductive parameters } \\
\hline Female mortality (\%) & 12 & 6 & NA \\
\hline Total spawns & 33 & 51 & NA \\
\hline Unfertilized spawns & 4 & 3 & NA \\
\hline Number of spawn/ablated female & 1.9 & 3.0 & NA \\
\hline Number of spawn/spawning female & 2.2 & 3.9 & NA \\
\hline Latency period (days) & $17 \pm 7^{\mathrm{a}}$ & $11 \pm 8^{\mathrm{b}}$ & $*$ \\
\hline Spawning females ${ }^{1}(\%)$ & 89 & 76 & NA \\
\hline Number of egg per spawn $\left(\times 10^{3}\right)$ & $33.5 \pm 11.2^{\mathrm{b}}$ & $71.9 \pm 34.5^{\mathrm{a}}$ & $* * *$ \\
\hline $\begin{array}{l}\text { Number of egg per spawn }\left(\times 10^{3}\right) \text { per } g \\
\text { of female's body weight }\end{array}$ & $1.7 \pm 0.6^{\mathrm{b}}$ & $2.6 \pm 1.3^{\mathrm{a}}$ & $* * *$ \\
\hline Fertilization rate $(\%)$ & $73.3 \pm 24.2$ & $85.1 \pm 14.8$ & ns \\
\hline Number of nauplii per spawn $\left(\times 10^{3}\right)$ & $25.6 \pm 12.5^{\mathrm{b}}$ & $51.9 \pm 31.8^{\mathrm{a}}$ & $* * *$ \\
\hline $\begin{array}{l}\text { Number of nauplii per spawn }\left(\times 10^{3}\right) \\
\text { per } \mathrm{g} \text { of spawner's body weight }\end{array}$ & $1.3 \pm 0.6$ & $1.8 \pm 1.1$ & ns \\
\hline Hatch rate $(\%)$ & $70.6 \pm 19.2$ & $68.1 \pm 21.8$ & ns \\
\hline Total eggs production $\left(\times 10^{3}\right)$ & 1071.8 & 3306.8 & NA \\
\hline Total nauplii production $\left(\times 10^{3}\right)$ & 487.5 & 2334.1 & NA \\
\hline \multicolumn{4}{|l|}{ Morphometric parameters } \\
\hline Female weight (g) & $19.6 \pm 2.2$ & $25.9 \pm 5.0$ & ns \\
\hline Zoea $^{2}$ weight (mg) & $5.4 \pm 0.3^{b}$ & $6.4 \pm 0.3^{\mathrm{a}}$ & * \\
\hline Zoea $^{2}$ length $(\mu \mathrm{m})$ & $911.5 \pm 24.6^{\mathrm{b}}$ & $923.7 \pm 28.5^{\mathrm{a}}$ & $* * *$ \\
\hline Mysis $^{2}$ weight (mg) & $56.2 \pm 11.3^{b}$ & $73.8 \pm 12.1^{\mathrm{a}}$ & $* * *$ \\
\hline Mysis $^{2}$ length (mm) & $2.9 \pm 1.3^{\mathrm{b}}$ & $3.2 \pm 1.8^{\mathrm{a}}$ & $* * *$ \\
\hline Postlarvae ${ }^{2}$ weight (mg) & $135.1 \pm 21.5^{\mathrm{b}}$ & $151.1 \pm 25.3^{\mathrm{a}}$ & $* * *$ \\
\hline Postlarvae $^{2}$ length (mm) & $4.4 \pm 1.3^{\mathrm{b}}$ & $4.5 \pm 1.8^{\mathrm{a}}$ & $* * *$ \\
\hline
\end{tabular}

Within rows, superscript letters indicate significant differences by Student's $T$ test $\left({ }^{*} \mathrm{P}<0.05 ;{ }^{* *} \mathrm{P}<0.01 ;{ }^{* * *} \mathrm{P}<0.001 ; n s=\right.$ no significant difference $)$.

$\mathrm{NA}=$ statistics not applicable

${ }^{1}$ Females that spawn at least once

${ }^{2}$ morphometric values of larval stage 1 .

7 maximum consecutive spawns, whilst domesticated population only presented 4 . HSI and GSI are shown in Fig. 3. No significant differences were observed $(\mathrm{P}>0.05)$, except by lower HSI in 1st spawn for wild females.

\subsection{Biochemical composition and FA profile}

The biochemical composition and FA profile results are given in Tables 2-4, respectively. Due to technical problems, FA measured in eggs from 4th spawn order was lost in domesticated samples. Significantly lower levels of AG in HP were observed in 1st spawn wild females than in domesticated females $(\mathrm{P}<0.05)$. Cholesterol levels (1st and 4th spawn order) were also lower in wild females than compared to domesticated ones $(\mathrm{P}<0.05)$. This trend were followed by lower ratios of $A G$ :TSP and $A G: C$ in 1 st spawn wild population $(\mathrm{P}<0.05)$. On the other hand, TSP levels presented no significant differences between treatments $(\mathrm{P}>0.05)$. FA profile performed in HP

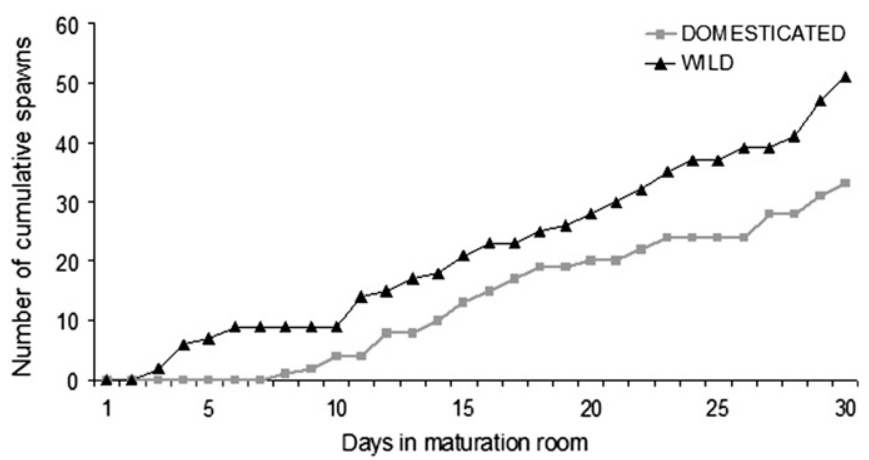

Fig. 1. Cumulative spawns of domesticated (G2) and wild $F$. duorarum broodstock in a 30-d experimental period from ablation.

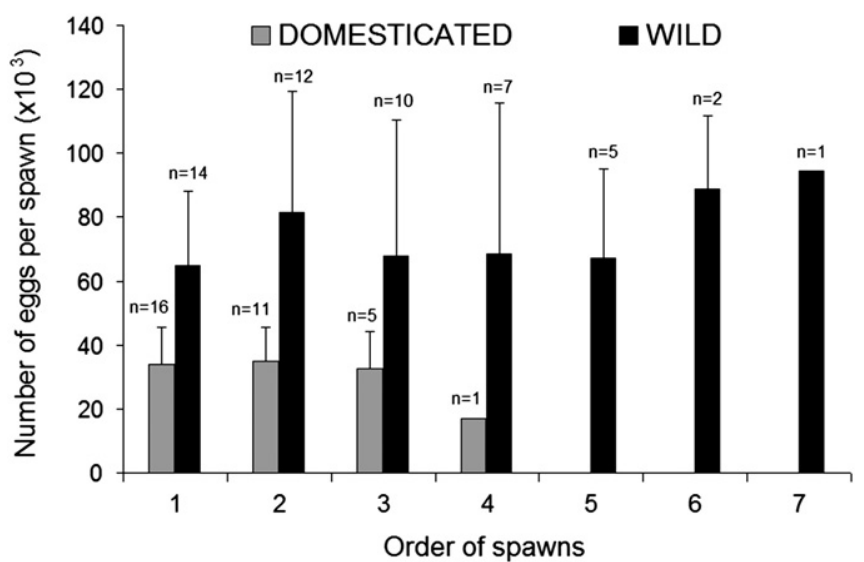

Fig. 2. Number of eggs per spawn (means \pm SD) in each spawn order from domesticated (G2) and wild $F$. duorarum broodstock in a 30-d experimental period.

showed that linoleic acid (LA), linolenic acid (ALA) and docosahexaenoic acid (DHA) mean levels were higher in domesticated females $(3.6,1.1$ and $9.7 \%$, respectively) as compared to wild ones (2.3, 0.6 and $8.8 \%$ ), whereas arachidonic acid (ARA), eicosapentanoic acid (EPA), sum of $\mathrm{n}-3$ and sum of n-6 were higher in wild females (5.0, 10.0 and 19.4 and $7.8 \%$, respectively) as compared to their domesticated counterparts (1.9, 3.3, 14.0 and 5.8\%). ARA, sum of n-3 and sum n-6 levels decreased over time (1st to the 4th spawn order) in both populations. On the other hand, LA, ALA and DHA levels increased over time in wild females contrasting with DHA levels that substantially decreased in domesticated females (14.9 to $4.4 \%$ ).

In hemolymph, TSP levels presented no differences in 1st spawn between domesticated and wild and 4th spawn for wild (107.2, 95.7 and $100.7 \mathrm{mg} \mathrm{mL}^{-1}$, respectively), but it was different in 4th spawn domesticated females $(\mathrm{P}<0.05)$ with higher levels $\left(179.8 \mathrm{mg} \mathrm{mL}^{-1}\right)$. Lower levels of glucose $\left(17.7 \mathrm{mg} \mathrm{dL}^{-1}\right)$ were observed in 1 st spawn wild females and hemocyanin levels were both lower in 1st and 4th spawn wild females $(\mathrm{P}<0.05)$ than domesticated ones.

In OV, significantly lower levels of AG $\left(15.8 \mathrm{mg} \mathrm{g}^{-1}\right)$ were observed in 1 st spawn domesticated females. Other metabolites

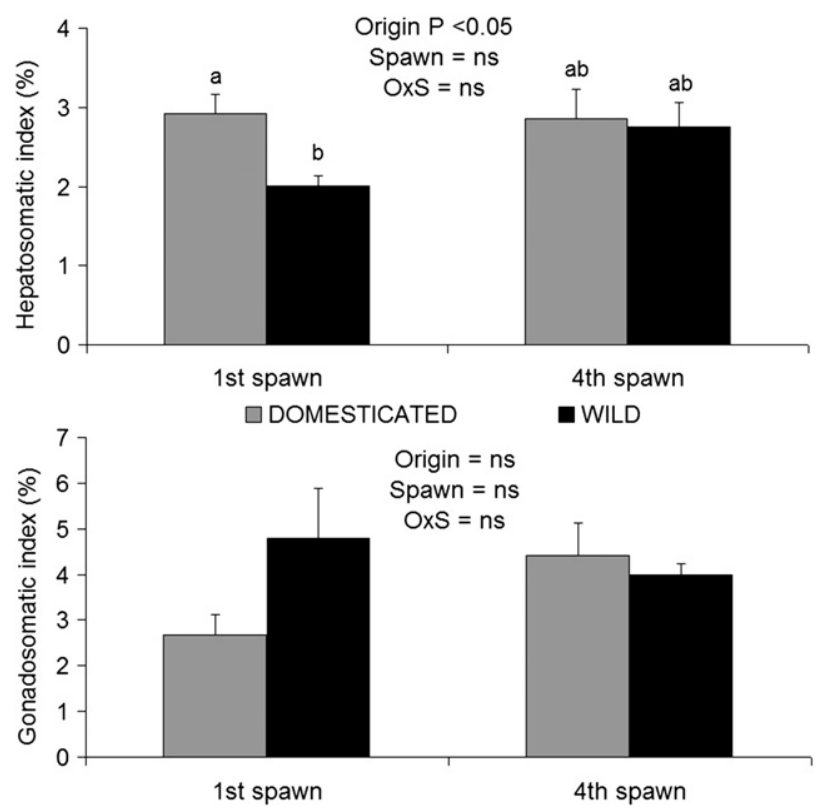

Fig. 3. Means $( \pm S E)$ of hepatosomatic index and gonadosomatic index from 1 st and 4 th spawn order of domesticated (G2) and wild F. duorarum broodstock in a 30-d experimental period. 
Table 2

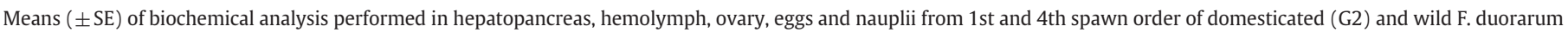
broodstock in a 30-d experimental period.

\begin{tabular}{|c|c|c|c|c|c|c|c|}
\hline \multirow[b]{2}{*}{ Variable } & \multicolumn{2}{|l|}{ Domesticated } & \multicolumn{2}{|l|}{ Wild } & \multicolumn{3}{|c|}{ Significance level $^{+}$} \\
\hline & 1st spawn & 4th spawn & 1st spawn & 4th spawn & Origin & Spawn & $O x P$ \\
\hline Hepatopancreas & $(n=6)$ & $(n=6)$ & $(n=5)$ & $(n=3)$ & & & \\
\hline Acylglycerides $\left(\mathrm{mg} \mathrm{g}^{-1}\right)$ & $66.5 \pm 10.3^{\mathrm{a}}$ & $32.7 \pm 9.1^{\mathrm{b}}$ & $9.1 \pm 2.0^{\mathrm{b}}$ & $91.0 \pm 2.4^{\mathrm{a}}$ & ns & * & $* * *$ \\
\hline Cholesterol $\left(\mathrm{mg} \mathrm{g}^{-1}\right)$ & $2.2 \pm 0.3^{\mathrm{ab}}$ & $2.7 \pm 0.03^{\mathrm{a}}$ & $1.6 \pm 0.2^{\mathrm{b}}$ & $1.4 \pm 0.3^{b}$ & $* * *$ & ns & ns \\
\hline Total sol. protein $\left(\mathrm{mg} \mathrm{g}^{-1}\right)$ & $28.2 \pm 1.1$ & $30.4 \pm 0.5$ & $30.4 \pm 0.9$ & $25.6 \pm 1.5$ & ns & ns & $* *$ \\
\hline AG:TSP & $2.4 \pm 0.4^{\mathrm{a}}$ & $1.6 \pm 0.2^{\mathrm{b}}$ & $0.4 \pm 0.5^{c}$ & $2.4 \pm 1.2^{\mathrm{a}}$ & ns & $*$ & $* * *$ \\
\hline$A G: C$ & $31.8 \pm 5.6^{\mathrm{ab}}$ & $18.1 \pm 1.9^{b}$ & $6.9 \pm 0.4^{c}$ & $41.4 \pm 21.7^{\mathrm{a}}$ & ns & $* * *$ & $* * *$ \\
\hline Hemolymph & $(n=6)$ & $(n=6)$ & $(n=5)$ & $(n=3)$ & & & \\
\hline Acylglycerides $\left(\mathrm{mg} \mathrm{dL}^{-1}\right)$ & $62.4 \pm 10.4$ & $53.5 \pm 7.7$ & $90.8 \pm 25.2$ & $65.8 \pm 24.7$ & ns & ns & ns \\
\hline Cholesterol $\left(\mathrm{mg} \mathrm{dL}^{-1}\right)$ & $22.1 \pm 4.1$ & $24.0 \pm 1.9$ & $23.2 \pm 2.6$ & $30.6 \pm 2.8$ & ns & ns & ns \\
\hline Total sol. protein $\left(\mathrm{mg} \mathrm{mL}^{-1}\right)$ & $107.2 \pm 16.2^{\mathrm{b}}$ & $179.8 \pm 16.0^{\mathrm{a}}$ & $95.7 \pm 5.7^{b}$ & $100.7 \pm 22.5^{\mathrm{ab}}$ & $*$ & $*$ & ns \\
\hline Glucose $\left(\mathrm{mg} \mathrm{dL}^{-1}\right)$ & $29.9 \pm 3.3^{\mathrm{a}}$ & $23.5 \pm 2.1^{\mathrm{ab}}$ & $17.7 \pm 2.0^{\mathrm{b}}$ & $29.7 \pm 6.0^{\mathrm{ab}}$ & ns & ns & * \\
\hline Hemocyanin $\left(\mathrm{mmol} \mathrm{L}^{-1}\right)$ & $2.1 \pm 0.2^{\mathrm{a}}$ & $2.2 \pm 0.2^{\mathrm{a}}$ & $1.2 \pm 0.3^{\mathrm{b}}$ & $1.3 \pm 0.3^{b}$ & $* *$ & ns & ns \\
\hline Ovary & $(n=6)$ & $(n=6)$ & $(n=5)$ & $(n=3)$ & & & \\
\hline Acylglycerides ( $\left.\mathrm{mg} \mathrm{g}^{-1}\right)$ & $15.8 \pm 1.4^{\mathrm{b}}$ & $32.9 \pm 6.5^{\mathrm{a}}$ & $26.5 \pm 2.4^{\mathrm{ab}}$ & $34.4 \pm 2.4^{\mathrm{a}}$ & * & * & ns \\
\hline Cholesterol $\left(\mathrm{mg} \mathrm{g}^{-1}\right)$ & $0.6 \pm 0.04$ & $0.96 \pm 0.2$ & $1.0 \pm 0.3$ & $0.9 \pm 0.2$ & ns & ns & ns \\
\hline Total sol. protein $\left(\mathrm{mg} \mathrm{g}^{-1}\right)$ & $25.9 \pm 2.7$ & $41.8 \pm 7.1$ & $38.9 \pm 7.6$ & $37.9 \pm 1.7$ & ns & ns & ns \\
\hline AG:TSP & $0.7 \pm 0.1$ & $0.6 \pm 0.1$ & $0.8 \pm 0.5$ & $0.6 \pm 0.2$ & ns & ns & ns \\
\hline AG:C & $29.5 \pm 3.5$ & $34.7 \pm 6.8$ & $37.3 \pm 10.0$ & $30.2 \pm 12.9$ & ns & ns & ns \\
\hline Eggs & $(n=9)$ & $(n=6)$ & $(n=9)$ & $(n=6)$ & & & \\
\hline Acylglycerides ( $\mathrm{mg} \mathrm{g}^{-1}$ ) & $19.5 \pm 0.8^{b}$ & $24.4 \pm 0.9^{\mathrm{a}}$ & $24.7 \pm 0.9^{\mathrm{a}}$ & $23.9 \pm 1.3^{\mathrm{a}}$ & * & * & $* *$ \\
\hline Cholesterol $\left(\mathrm{mg} \mathrm{g}^{-1}\right)$ & $7.4 \pm 0.2$ & $6.7 \pm 0.8$ & $6.8 \pm 0.3$ & $6.5 \pm 0.4$ & ns & ns & ns \\
\hline Total sol. protein $\left(\mathrm{mg} \mathrm{g}^{-1}\right)$ & $122.2 \pm 13.4^{\mathrm{b}}$ & $181.6 \pm 17.9^{a}$ & $113.7 \pm 10.8^{\mathrm{b}}$ & $176.6 \pm 32.8^{a}$ & ns & $* * *$ & ns \\
\hline AG:TSP & $0.2 \pm 0.2^{\mathrm{ab}}$ & $0.1 \pm 0.1^{\mathrm{b}}$ & $0.2 \pm 0.2^{\mathrm{ab}}$ & $0.4 \pm 0.1^{\mathrm{a}}$ & $* *$ & ns & ns \\
\hline$A G: C$ & $2.7 \pm 0.2^{\mathrm{b}}$ & $3.9 \pm 0.3^{a}$ & $3.7 \pm 0.2^{\mathrm{a}}$ & $3.7 \pm 0.3^{\mathrm{a}}$ & ns & $*$ & $*$ \\
\hline Nauplii & $(n=9)$ & $(n=6)$ & $(n=9)$ & $(n=6)$ & & & \\
\hline Acylglycerides ( $\left.\mathrm{mg} \mathrm{g}^{-1}\right)$ & $13.6 \pm 0.5$ & $12.3 \pm 1.2$ & $13.2 \pm 0.6$ & $13.9 \pm 0.9$ & ns & ns & ns \\
\hline Cholesterol $\left(\mathrm{mg} \mathrm{g}^{-1}\right)$ & $3.2 \pm 0.2^{b}$ & $4.9 \pm 0.8^{\mathrm{a}}$ & $3.7 \pm 0.2^{\mathrm{b}}$ & $4.3 \pm 0.2^{\mathrm{a}}$ & ns & $* *$ & ns \\
\hline Total sol. protein $\left(\mathrm{mg} \mathrm{g}^{-1}\right)$ & $72.9 \pm 5.5^{\mathrm{a}}$ & $62.5 \pm 8.6^{\mathrm{a}}$ & $42.3 \pm 2.3^{b}$ & $33.2 \pm 7.3^{b}$ & $* * *$ & ns & ns \\
\hline AG:TSP & $0.6 \pm 0.2$ & $0.5 \pm 0.3$ & $0.3 \pm 0.2$ & $0.8 \pm 0.3$ & ns & ns & ns \\
\hline AG:C & $4.4 \pm 0.2^{\mathrm{a}}$ & $3.0 \pm 0.3^{b}$ & $3.7 \pm 0.2^{\mathrm{ab}}$ & $3.3 \pm 0.3^{\mathrm{ab}}$ & ns & $* *$ & ns \\
\hline
\end{tabular}

Within rows, superscript letters indicate significant differences by Post-hoc Tukey test $(P=0.05)$.

${ }^{+}$Bi-factorial ANOVA where ${ }^{*} P<0.05 ;{ }^{* *} P<0.01 ;{ }^{* * *} P<0.001 ; n s=$ no significant difference

presented no significant differences $(\mathrm{P}>0.05)$. LA, ALA, DHA and sum of n-3 mean levels were higher in domesticated females (2.6, $0.8,15.1$ and $26.3 \%$, respectively) as compared to wild ones (2.2, 0.5, 9.9 and 22.4\%), whereas ARA, EPA and sum of $n-6$ were higher in wild females $(4.9,12.0$ and $7.3 \%$, respectively) than in their domesticated counterparts (3.3, 10.5 and 5.9\%). Moreover, LA, ALA and sum of n-6 levels decreased over time in domesticated population, as well as ARA and EPA in wild ones. On the other hand, LA, sum of n-3 and mainly DHA (6.6 to $13.2 \%$ ) increased over time in wild population (Table 3).

Eggs from 1st spawn domesticated females presented significantly the lowest values of AG $(\mathrm{P}<0.05)$. TSP levels increased in 4th spawns eggs in both origins $(\mathrm{P}<0.05)$. In domesticated population, AG:TSP ratio was significantly lower and AG:C increased over time $(P<0.05)$ (Table 2). FA profile measured in eggs (Table 4) showed that LA, ALA, ARA and sum of $n-6$ levels were similar and maintained stable over time in both treatments. On the other hand, EPA, DHA and sum of $n-3$ mean levels were higher in domesticated eggs $(7.5,10.1$ and $18.4 \%$, respectively) and increased over time as compared to low mean levels of wild ones (6.6, 8.5 and 15.7\%) in which EPA, DHA and sum of $n-3$ levels decreased from 1st to the 2nd spawn order and then increased over time.

In nauplii, 1st spawn domesticated females presented the lowest levels of cholesterol with $3.2 \mathrm{mg} \mathrm{g}^{-1}$ although not significantly different with wild ones $\left(3.7 \mathrm{mg} \mathrm{g}^{-1}\right)$. However, both 4 th spawns origins presented significantly higher values with 4.9 and $4.3 \mathrm{mg} \mathrm{g}^{-1}$ for domesticated and wild, respectively $(\mathrm{P}<0.05)$. TSP levels were lower in wild population for both 1 st and 4 th spawn order $(\mathrm{P}<0.05)$. AG:C ratio decreased as the spawn order increased both in wild and domesticated females $(\mathrm{P}<0.05)$. AG and AG:TSP presented no differences between treatments $(\mathrm{P}>0.05)$.

\subsection{Multivariate analysis}

EOF energetic modes of variation and percentage of the total mode 1 energy for the most energetic variable (MEV) are summarized in Table 5. Results indicated that overall variance was captured in more than $80 \%$ for mode 1 , except by 1 st spawn OV data for wild and domesticated as well as 4th spawn OV data for domesticated females. AG was the MEV and responded for most variance with energy retention with more than $85 \%$ in all cases. AG as MEV was also showed in Fig. 4 that includes the biochemical status of 1 st and 4 th spawn, indicating the same general trend for both origins in all tissues.

\section{Discussion}

\subsection{Reproductive performance}

In the past years, many studies reported a better reproductive performance in wild populations as compared to domesticated ones (Keys and Crocos, 2006; Menasveta et al., 1993; Mendoza, 1997; Regunathan, 2008). These results have been explained by the high pressure in natural selection suffered by wild populations (selecting the strongest and healthiest animals) as well as the consumption of high quality variety natural food items in wild. On the other hand, domesticated conditions offer a limited variety of food items, mainly based 
Table 3

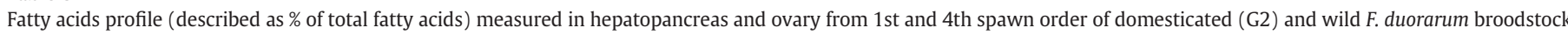
in a 30-d experimental period.

\begin{tabular}{|c|c|c|c|c|c|c|c|c|c|c|c|c|c|c|c|c|c|c|c|c|}
\hline \multirow[b]{3}{*}{ Fatty acid } & \multicolumn{10}{|c|}{ Hepatopancreas } & \multicolumn{10}{|c|}{ Ovary } \\
\hline & \multicolumn{5}{|c|}{ Domesticated } & \multicolumn{5}{|l|}{ Wild } & \multicolumn{5}{|c|}{ Domesticated } & \multicolumn{5}{|l|}{ Wild } \\
\hline & $1 \mathrm{st}$ & 4th & Means & & $S D$ & $1 \mathrm{st}$ & 4th & Means & & $S D$ & $1 \mathrm{st}$ & 4th & Means & & $S D$ & $1 \mathrm{st}$ & 4 th & Means & & $S D$ \\
\hline C14:0 & 2.8 & 3.8 & 3.3 & \pm & 0.7 & 2.2 & 3.5 & 2.9 & \pm & 0.9 & 1.8 & 2.3 & 2.1 & \pm & 0.4 & 3.4 & 2.0 & 2.7 & \pm & 0.9 \\
\hline C15:0 & 0.9 & 1.2 & 1.1 & \pm & 0.2 & 2.5 & 1.0 & 1.7 & \pm & 1.1 & 0.5 & 0.4 & 0.5 & \pm & 0.1 & 3.3 & 0.5 & 1.9 & \pm & 2.0 \\
\hline $\mathrm{C} 16: 0$ & 28.5 & 30.4 & 29.4 & \pm & 1.4 & 20.3 & 31.9 & 26.1 & \pm & 8.2 & 21.7 & 24.3 & 23.0 & \pm & 1.9 & 20.7 & 21.7 & 21.2 & \pm & 0.7 \\
\hline C16:1 n-7 & 6.7 & 8.8 & 7.7 & \pm & 1.5 & 7.2 & 6.3 & 6.7 & \pm & 0.7 & 4.6 & 6.4 & 5.5 & \pm & 1.3 & 10.4 & 4.9 & 7.6 & \pm & 3.9 \\
\hline C17:0 & 1.1 & 1.3 & 1.2 & \pm & 0.1 & 4.3 & 1.5 & 2.9 & \pm & 2.0 & 1.1 & 1.0 & 1.0 & \pm & 0.1 & 3.6 & 0.9 & 2.2 & \pm & 1.9 \\
\hline C18:0 & 5.0 & 6.1 & 5.6 & \pm & 0.8 & 10.9 & 7.1 & 9.0 & \pm & 2.7 & 7.0 & 6.9 & 6.9 & \pm & 0.1 & 6.8 & 5.9 & 6.4 & \pm & 0.6 \\
\hline C18:1 n-7 & 8.0 & 9.5 & 8.7 & \pm & 1.1 & 4.6 & 5.4 & 5.0 & \pm & 0.6 & 5.5 & 4.6 & 5.1 & \pm & 0.6 & 5.4 & 5.3 & 5.3 & \pm & 0.1 \\
\hline C18:1 n-9 & 13.9 & 17.6 & 15.8 & \pm & 2.6 & 8.8 & 12.5 & 10.6 & \pm & 2.6 & 18.2 & 19.2 & 18.7 & \pm & 0.8 & 12.9 & 20.9 & 16.9 & \pm & 5.7 \\
\hline C18:2 n-6 (LA) & 3.7 & 3.4 & 3.6 & \pm & 0.3 & 0.6 & 3.9 & 2.3 & \pm & 2.3 & 3.6 & 1.6 & 2.6 & \pm & 1.4 & 0.8 & 3.6 & 2.2 & \pm & 2.0 \\
\hline C18:3 n-3 (ALA) & 1.3 & 0.8 & 1.1 & \pm & 0.3 & 0.4 & 0.8 & 0.6 & \pm & 0.3 & 1.0 & 0.5 & 0.8 & \pm & 0.4 & 0.5 & 0.6 & 0.5 & \pm & 0.1 \\
\hline C18:3 n-6 & 0.1 & 0.3 & 0.2 & \pm & 0.1 & 0.2 & 0.1 & 0.1 & \pm & 0.1 & 0.0 & 0.0 & 0.0 & \pm & 0.0 & 0.0 & 0.3 & 0.1 & \pm & 0.2 \\
\hline $\mathrm{C} 20: 0$ & 0.2 & 0.2 & 0.2 & \pm & 0.0 & 0.4 & 0.3 & 0.4 & \pm & 0.1 & 0.5 & 0.5 & 0.5 & \pm & 0.0 & 0.5 & 0.5 & 0.5 & \pm & 0.0 \\
\hline C20:1 n-9 & 3.7 & 4.6 & 4.2 & \pm & 0.6 & 1.0 & 3.3 & 2.2 & \pm & 1.6 & 1.5 & 2.0 & 1.8 & \pm & 0.3 & 0.8 & 2.4 & 1.6 & \pm & 1.1 \\
\hline $\mathrm{C} 20: 2$ & 1.0 & 0.9 & 1.0 & \pm & 0.1 & 1.7 & 0.8 & 1.3 & \pm & 0.7 & 0.6 & 0.5 & 0.6 & \pm & 0.1 & 1.1 & 0.8 & 0.9 & \pm & 0.3 \\
\hline$C 20: 3 n-6$ & 0.3 & 0.0 & 0.1 & \pm & 0.2 & 0.5 & 0.3 & 0.4 & \pm & 0.1 & 0.2 & 0.0 & 0.1 & \pm & 0.1 & 0.0 & 0.2 & 0.1 & \pm & 0.2 \\
\hline C20:4 n-6 (ARA) & 2.3 & 1.6 & 1.9 & \pm & 0.5 & 8.0 & 2.0 & 5.0 & \pm & 4.2 & 3.2 & 3.3 & 3.3 & \pm & 0.0 & 6.4 & 3.3 & 4.9 & \pm & 2.2 \\
\hline C20:5 n-3 (EPA) & 3.3 & 3.3 & 3.3 & \pm & 0.0 & 13.4 & 6.6 & 10.0 & \pm & 4.8 & 10.8 & 10.1 & 10.5 & \pm & 0.5 & 13.0 & 11.0 & 12.0 & \pm & 1.4 \\
\hline C22:6 n-3 (DHA) & 14.9 & 4.4 & 9.7 & \pm & 7.4 & 8.0 & 9.5 & 8.8 & \pm & 1.1 & 15.6 & 14.5 & 15.1 & \pm & 0.8 & 6.6 & 13.2 & 9.9 & \pm & 4.7 \\
\hline$\sum$ Saturated & 38.5 & 43.0 & 40.7 & \pm & 3.2 & 40.6 & 45.4 & 43.0 & \pm & 3.4 & 32.6 & 35.5 & 34.1 & \pm & 2.0 & 38.2 & 31.6 & 34.9 & \pm & 4.7 \\
\hline$\sum$ Monounsaturated & 32.4 & 40.5 & 36.4 & \pm & 5.8 & 21.6 & 27.4 & 24.5 & \pm & 4.1 & 29.8 & 32.3 & 31.0 & \pm & 1.7 & 29.4 & 33.5 & 31.5 & \pm & 2.9 \\
\hline$\sum n-3$ & 19.5 & 8.6 & 14.0 & \pm & 7.7 & 21.8 & 17.0 & 19.4 & \pm & 3.4 & 27.5 & 25.1 & 26.3 & \pm & 1.7 & 20.0 & 24.8 & 22.4 & \pm & 3.4 \\
\hline$\sum \mathrm{n}-6$ & 6.5 & 5.2 & 5.8 & \pm & 0.9 & 9.3 & 6.3 & 7.8 & \pm & 2.1 & 7.1 & 4.8 & 5.9 & \pm & 1.6 & 7.2 & 7.4 & 7.3 & \pm & 0.2 \\
\hline$(n-3) /(n-6)$ & 3.0 & 1.6 & 2.3 & \pm & 1.0 & 2.3 & 2.7 & 2.5 & \pm & 0.2 & 3.9 & 5.2 & 4.6 & \pm & 0.9 & 2.8 & 3.3 & 3.1 & \pm & 0.4 \\
\hline
\end{tabular}

on dry commercial pellet and a relatively limited choice of fresh or frozen items such as squid, mussels, worms, Artemia biomass and others.

The spawning frequency or number of spawns per time unit is considered as an important criterion to evaluate broodstock performance (Ibarra et al., 2007). In the present study, wild females had 1.7 times more spawns per spawning female than domesticated females. Wild females spawned 3.9 times per spawning female as an average, with a maximum of 7 spawns during 30 days compared to 4 reached by domesticated females. These values are higher than observed in wild or domesticated Penaeus esculentus (Keys and Crocos, 2006), F. paulensis (Peixoto et al., 2008) Fenneropenaeus indicus (Regunathan, 2008) and L. stylirostris (Mendoza, 1997) but similar than those reported for pond-reared L. stylirostris (Wabete et al., 2006), L. vannamei (Arcos et al., 2003) and wild and pond-reared P. monodon with max. of 7 and 3 maturations per female, respectively (Menasveta et al., 1993).

Latency period is directly related to the capacity of multiple spawning (Arcos et al., 2003; Palacios et al., 1999a) and a shorter latency period in wild females observed in this study (11 vs 17 days for wild and

Table 4

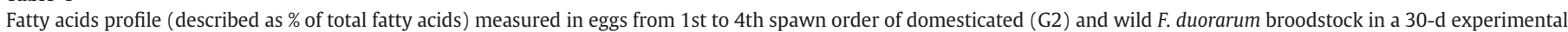
period.

\begin{tabular}{|c|c|c|c|c|c|c|c|c|c|c|c|c|c|c|}
\hline \multirow[b]{3}{*}{ Fatty acid } & \multicolumn{14}{|l|}{ Eggs } \\
\hline & \multicolumn{7}{|c|}{ Domesticated } & \multicolumn{7}{|l|}{ Wild } \\
\hline & $1 \mathrm{st}$ & 2nd & 3rd & 4th & Means & & $S D$ & $1 \mathrm{st}$ & 2nd & 3rd & 4th & Means & & $S D$ \\
\hline $\mathrm{C} 14: 0$ & 1.5 & 2.0 & 2.3 & NA & 1.9 & \pm & 0.4 & 3.5 & 3.7 & 3.5 & 3.2 & 3.5 & \pm & 0.2 \\
\hline $\mathrm{C} 15: 0$ & 0.7 & 0.6 & 0.6 & NA & 0.6 & \pm & 0.1 & 0.8 & 1.0 & 1.0 & 0.7 & 0.9 & \pm & 0.1 \\
\hline $\mathrm{C} 16: 0$ & 27.6 & 25.6 & 26.0 & NA & 26.4 & \pm & 1.1 & 26.5 & 27.0 & 27.6 & 27.8 & 27.2 & \pm & 0.6 \\
\hline C16:1 n-7 & 5.2 & 5.7 & 5.6 & NA & 5.5 & \pm & 0.3 & 8.5 & 9.4 & 8.4 & 7.2 & 8.4 & \pm & 0.9 \\
\hline $\mathrm{C} 17: 0$ & 1.7 & 1.4 & 1.4 & NA & 1.5 & \pm & 0.2 & 1.3 & 1.6 & 1.6 & 1.3 & 1.5 & \pm & 0.2 \\
\hline C18:0 & 10.6 & 8.9 & 8.9 & NA & 9.5 & \pm & 1.0 & 7.2 & 7.9 & 7.8 & 8.3 & 7.8 & \pm & 0.4 \\
\hline C18:1 n-7 & 7.0 & 6.7 & 5.8 & NA & 6.5 & \pm & 0.6 & 0.0 & 5.8 & 5.9 & 6.3 & 4.5 & \pm & 3.0 \\
\hline C18:1 n-9 & 20.0 & 19.7 & 19.2 & NA & 19.6 & \pm & 0.4 & 17.7 & 18.6 & 18.4 & 18.3 & 18.2 & \pm & 0.4 \\
\hline C18:2 n-6 (LA) & 2.7 & 3.1 & 2.8 & NA & 2.9 & \pm & 0.2 & 2.5 & 2.8 & 2.6 & 2.6 & 2.6 & \pm & 0.1 \\
\hline C18:3 n-3 (ALA) & 0.7 & 0.9 & 0.9 & NA & 0.8 & \pm & 0.1 & 0.6 & 0.6 & 0.6 & 0.7 & 0.6 & \pm & 0.0 \\
\hline$C 18: 3 n-6$ & 0.0 & 0.0 & 0.0 & NA & 0.0 & \pm & 0.0 & 0.1 & 0.1 & 0.1 & 0.0 & 0.1 & \pm & 0.0 \\
\hline $\mathrm{C} 20: 0$ & 0.9 & 0.6 & 0.6 & NA & 0.7 & \pm & 0.1 & 0.6 & 0.6 & 0.6 & 0.6 & 0.6 & \pm & 0.0 \\
\hline C20:1 n-9 & 2.1 & 1.7 & 1.8 & NA & 1.9 & \pm & 0.2 & 2.4 & 2.1 & 2.3 & 2.2 & 2.3 & \pm & 0.2 \\
\hline $\mathrm{C} 20: 2$ & 0.6 & 0.6 & 0.5 & NA & 0.6 & \pm & 0.1 & 0.5 & 0.5 & 0.5 & 0.4 & 0.5 & \pm & 0.0 \\
\hline$c 20: 3$ n-6 & 0.0 & 0.1 & 0.2 & NA & 0.1 & \pm & 0.1 & 0.2 & 0.2 & 0.2 & 0.1 & 0.2 & \pm & 0.0 \\
\hline C20:4 n-6 (ARA) & 2.1 & 2.3 & 2.3 & NA & 2.2 & \pm & 0.1 & 1.9 & 2.0 & 1.9 & 1.7 & 1.9 & \pm & 0.1 \\
\hline C20:5 n-3 (EPA) & 6.4 & 8.1 & 7.9 & NA & 7.5 & \pm & 0.9 & 7.0 & 5.9 & 6.4 & 6.9 & 6.6 & \pm & 0.5 \\
\hline $\mathrm{C} 22: 6 \mathrm{n}-3$ (DHA) & 8.8 & 10.3 & 11.2 & NA & 10.1 & \pm & 1.2 & 10.9 & 6.9 & 7.3 & 9.0 & 8.5 & \pm & 1.8 \\
\hline$\sum$ Saturated & 43.0 & 39.1 & 39.8 & NA & 40.6 & \pm & 2.1 & 39.9 & 41.8 & 42.2 & 41.9 & 41.5 & \pm & 1.1 \\
\hline$\sum$ Monounsaturated & 34.2 & 33.7 & 32.4 & NA & 33.4 & \pm & 0.9 & 28.5 & 35.9 & 35.1 & 34.0 & 33.4 & \pm & 3.3 \\
\hline$\sum n-3$ & 16.0 & 19.3 & 20.0 & NA & 18.4 & \pm & 2.2 & 18.4 & 13.5 & 14.4 & 16.6 & 15.7 & \pm & 2.2 \\
\hline$\sum n-6$ & 4.7 & 5.5 & 5.3 & NA & 5.2 & \pm & 0.4 & 4.7 & 5.1 & 4.7 & 4.4 & 4.7 & \pm & 0.3 \\
\hline$(n-3) /(n-6)$ & 3.4 & 3.5 & 3.8 & NA & 3.5 & \pm & 0.2 & 3.9 & 2.7 & 3.0 & 3.8 & 3.4 & \pm & 0.6 \\
\hline
\end{tabular}

$\mathrm{NA}=$ not available. 
Table 5

Multivariate analysis using Empirical Orthogonal Function (EOF) of acylglycerides (AG), cholesterol (chol.) and total soluble protein (TSP) biochemical data (first and fourth spawns) performed in hepatopancreas, hemolymph, ovary, eggs and nauplii from domesticated (G2) and wild F. duorarum broodstock in a 30-d experimental period. Data shows the more energetic modes of variation (Modes 1,2 and 3) and percentage of the total mode 1 energy for the "most energetic variable" (MEV).

\begin{tabular}{|c|c|c|c|c|c|c|c|c|}
\hline \multirow{2}{*}{$\begin{array}{l}\text { 1st spawn order } \\
\text { Tissue }\end{array}$} & \multirow[t]{2}{*}{ Origin } & \multicolumn{3}{|c|}{$\begin{array}{l}\text { EOF's energetic } \\
\text { modes of variation } \\
(\%)\end{array}$} & \multirow[t]{2}{*}{ MEV } & \multicolumn{3}{|c|}{$\begin{array}{l}\text { MEV Mode } 1 \\
\text { energy retention } \\
(\%)\end{array}$} \\
\hline & & $\begin{array}{l}\text { Mode } \\
1\end{array}$ & $\begin{array}{l}\text { Mode } \\
2\end{array}$ & $\begin{array}{l}\text { Mode } \\
3\end{array}$ & & AG & Chol. & TSP \\
\hline Hepatopancreas & Wild & 84.5 & 8.5 & 7.1 & AG & 97.5 & 2.5 & 0.1 \\
\hline Hepatopancreas & Domesticated & 97.8 & 1.7 & 0.6 & AG & 99.9 & 0.1 & 0.0 \\
\hline Hemolymph & Wild & 92.5 & 6.7 & 0.7 & AG & 95.5 & 4.5 & 0.0 \\
\hline Hemolymph & Domesticated & 94.5 & 4.5 & 1.0 & AG & 88.7 & 11.3 & 0.0 \\
\hline Ovary & Wild & 67.9 & 25.0 & 7.1 & AG & 88.4 & 11.6 & 0.0 \\
\hline Ovary & Domesticated & 63.3 & 34.1 & 2.6 & AG & 89.7 & 10.2 & 0.2 \\
\hline Eggs & Wild & 92.0 & 4.7 & 3.3 & AG & 93.2 & 6.8 & 0.0 \\
\hline Eggs & Domesticated & 90.7 & 5.7 & 3.6 & AG & 87.8 & 12.2 & 0.0 \\
\hline Nauplii & Wild & 89.7 & 6.1 & 4.2 & AG & 93.0 & 7.0 & 0.0 \\
\hline Nauplii & Domesticated & 89.8 & 6.6 & 3.6 & AG & 94.9 & 5.1 & 0.0 \\
\hline 4th spawn order & Origin & \multicolumn{3}{|c|}{$\begin{array}{l}\text { EOF's energetic } \\
\text { modes of variation } \\
(\%)\end{array}$} & MEV & \multicolumn{3}{|c|}{$\begin{array}{l}\text { MEV Mode } 1 \\
\text { energy retention } \\
(\%)\end{array}$} \\
\hline Tissue & & $\begin{array}{l}\text { Mode } \\
1\end{array}$ & $\begin{array}{l}\text { Mode } \\
2\end{array}$ & $\begin{array}{l}\text { Mode } \\
3\end{array}$ & & AG & Chol. & TSP \\
\hline Hepatopancreas & Wild & 98.1 & 1.2 & 0.7 & AG & 100.0 & 0.0 & 0.0 \\
\hline Hepatopancreas & Domesticated & 94.3 & 3.5 & 2.2 & AG & 99.7 & 0.3 & 0.0 \\
\hline Hemolymph & Wild & 84.4 & 15.1 & 0.4 & AG & 87.7 & 12.3 & 0.0 \\
\hline Hemolymph & Domesticated & 92.4 & 6.3 & 1.4 & AG & 84.5 & 15.5 & 0.0 \\
\hline Ovary & Wild & 82.2 & 17.7 & 0.1 & AG & 94.9 & 5.1 & 0.0 \\
\hline Ovary & Domesticated & 76.9 & 18.0 & 5.1 & AG & 92.0 & 7.4 & 0.6 \\
\hline Eggs & Wild & 93.9 & 3.6 & 2.5 & AG & 93.2 & 6.8 & 0.0 \\
\hline Eggs & Domesticated & 92.4 & 4.7 & 2.8 & AG & 92.7 & 7.3 & 0.0 \\
\hline Nauplii & Wild & 91.7 & 6.1 & 2.2 & AG & 91.5 & 8.5 & 0.0 \\
\hline Nauplii & Domesticated & 83.1 & 11.3 & 5.6 & AG & 86.6 & 13.4 & 0.0 \\
\hline
\end{tabular}

domesticated, respectively) is consistent with a higher spawning rate. The same trend was observed for other species such as $F$. paulensis (Cavalli et al., 1997), P. monodon (Menasveta et al., 1993) and L. vannamei (Palacios et al., 1999a) where wild females started spawning earlier and presented a higher spawning frequency than those kept in culture ponds. A better nutritional physiology condition of eyestalk ablated females from wild could be the main causative agent, increasing their capacity of multiple spawning.

In a shrimp hatchery a large percentage of females in any production cycle spawned only once or sometimes never spawn, whereas only a small percentage is able to spawn several times (Cavalli et al., 1997; Palacios et al., 1999b). In contrast to other indicators of reproductive capacity, domesticated population presented a better performance in terms of spawning females than wild ones (89 vs $76 \%$ of females that spawned at least once). This result contrasted to Cavalli et al. (1997) in which the proportion of wild $F$. paulensis that never spawned was lower than for their domesticated counterparts.

The number of eggs and viable nauplii produced per spawns also represent quantitative criteria to evaluate broodstock performance and a way to exclude the poor strains, reducing costs in shrimp maintenance (Racotta et al., 2004). In the present study, both egg and nauplii production was higher for wild females. Furthermore, number of eggs per spawn increased over time in wild females whereas decreased for their domesticated counterparts (Fig. 2), corroborating with Peixoto et al. (2004) in which captive tank-reared F. paulensis females decreased the eggs production over time as compared to wild ones. A comparison of egg production per unit of body weight is presented in Table 6. In our study, F. duorarum outcomes, mainly represented by wild females, performed better results as compared with other wild populations as F. indicus (Regunathan, 2008), P. semisulcatus (Browdy et al., 1986), F. paulensis (Cavalli et al., 1997), L. stylirostris (Mendoza, 1997) and
P. esculentus (Keys and Crocos, 2006). On the other hand, it was poorer than wild P. monodon (Menasveta et al., 1993) and L. vannamei (Ibarra et al., 1997). In contrast to reproductive quantitative output, spawn quality in terms of fertilization and hatch rates was not different between wild and domesticated populations. However zoea, mysis and postlavae weight and length, considered as indicators of larval quality (for review see Racotta et al., 2003, 2004; Arcos et al., 2005b), was higher in wild as compared to domesticated population, suggesting a superior quality that will be analyzed together with biochemical indicators of spawn and larval quality.

\subsection{Biochemical composition and FA profile}

Multiple spawning capacities could involve a decrease in spawn quality and nutrient storage (such as lipids and essential FA) over consecutive spawns (Emmerson, 1980; Palacios et al., 1999b, 2000). Substantial part of ovarian total lipids in the early stage of maturation must come from diet intake (Hoa et al., 2009) and sufficient levels will be accumulated in (i) HP and hemolymph to allow successive spawns (Palacios et al., 2000; Tseng et al., 2001) and (ii) in the egg yolk to guarantee the normal development of the embryos and prefeeding larvae (Teshima and Kanazawa, 1983; Wouters et al., 2001b). A large fraction of these lipids is composed by HUFA, especially DHA, EPA and ARA (Hoa et al., 2009). The importance of dietary HUFA for crustacean maturation and reproduction has been well described (Cahu et al., 1994, Harrison, 1990; Lytle et al., 1990; Teshima et al., 1988; Wouters et al., 2001c). ARA and EPA are essential components of cell membranes and precursors for 2-series and 3-series prostaglandins (Tahara and Yano, 2004), whereas DHA plays an important role as a source of energy and on the development of the central nervous system in crustaceans (Xu et al., 1994). On the other hand, the knowledge on a specific nutrient requirement for enhancement of reproductive performance remains limited and spawning outcomes could not be dependent to a single nutrient (Regunathan, 2008). For F. duorarum wild juveniles, previous studies in Celestún estuaries, Mexico, reported a preference on copepods and amphipods (Aragón-Axomulco et al., accepted for publication), lipids and protein-rich food items. Furthermore, amount and quality of broodstock food intake in wild is hard to measure.

The digestive gland HP is an important gland for storage of nutrients such as lipids (Cahu et al., 1994; Marsden et al., 2007), protein (Marsden et al., 2007; Palacios et al., 2000), carbohydrates (Arcos et al., 2003; Nakayama et al., 2008), carotenoids (Arcos et al., 2003), vitamins (Shiau and Wu, 2003), essential FA and amino acids (Cahu et al., 1994; Millamena and Pascual, 1990). Successive spawns imply a continuous transfer of nutrients to eggs and it is therefore expected to gradually deplete lipid reserves in HP as previously shown in P. indicus (Vazquez Boucard et al., 2004) and this would explain the 50\% decrease in AG levels observed in the present study for domesticated females from the 1 st to the 4th spawn. However this depletion is not always observed and could depend on adequate maturation conditions, particularly the diet (Palacios et al., 2000). This seems to be the case in wild females in which AG levels in HP of females at their 4th spawn were three-fold higher than in domesticated females. Moreover, the 10 -fold increase observed from the 1st to the 4th spawn in wild females was mainly because they start with very low levels of AG at their first spawn, which also was observed for the sum of total FA (not shown), LA, ALA, DHA and also was related with low HSI. On the other hand, DHA levels and sum of n-3 in HP from domesticated females decreased between the 1st and the 4th spawn order possibly due to slow response to ablation in domesticated population, also corroborated with high HSI and low GSI. In P. monodon, lipid levels decreased to meet a need for rapid development of OV following eyestalk ablation in ablated females (Marsden et al., 2007). Thus the initial low levels of AG in our study in wild females could be explained by a more accentuated response to eyestalk ablation of wild population as compared to domesticated ones. Indeed, wild females spawned more promptly, had a higher number of 

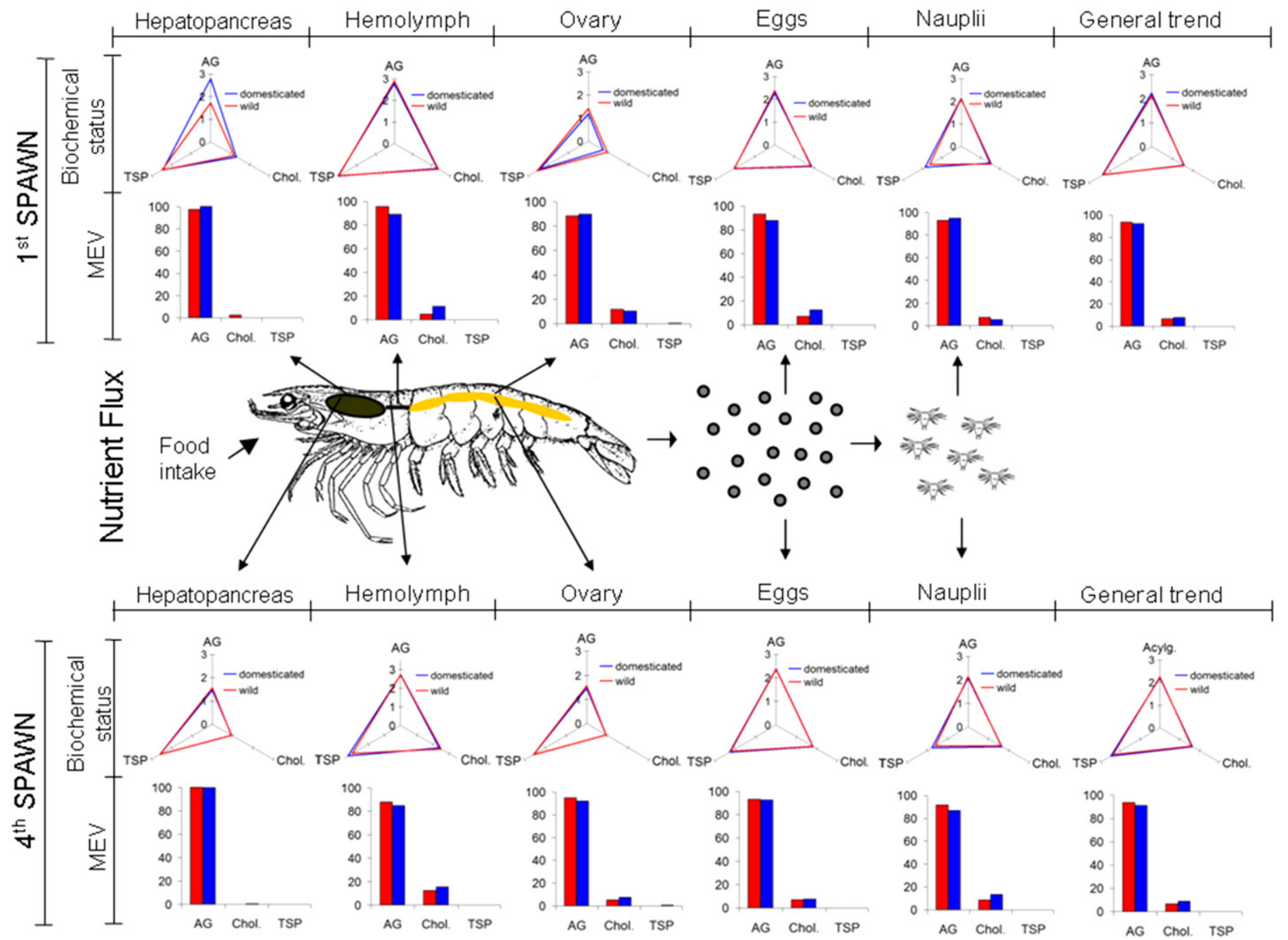

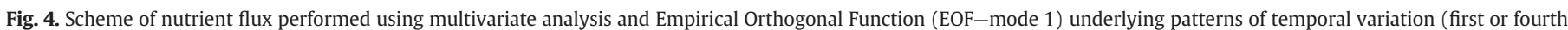

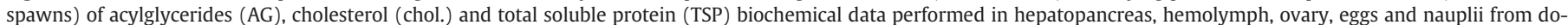
mesticated (G2) and wild F. duorarum broodstock. Data shows biochemical status and most energetic variable (MEV) from mode 1 , expressed in \%.

Table 6

Data from egg productivity (eggs per spawn per g of female's body weight) in some penaeid species.

\begin{tabular}{|c|c|c|c|}
\hline Species and origin & $\begin{array}{l}\text { Eggs per spawn } \\
\text { per } g \text { of female's } \\
\text { body weight } \\
\left(\times 10^{3}\right)\end{array}$ & $\begin{array}{l}\text { Female } \\
\text { weight } \\
\text { (g) }\end{array}$ & Reference \\
\hline P. monodon (wild) & 3.92 & 205.3 & Menasveta et al. (1993) \\
\hline P. monodon (pond-reared G2) & 1.95 & 133.3 & Menasveta et al. (1993) \\
\hline L. vannamei (wild) & 3.85 & 45.38 & Ibarra et al. (1997) \\
\hline L. vannamei (pond-reared) & 2.67 & 33.76 & Ibarra et al. (1997) \\
\hline F. indicus (wild) & 2.37 & 33.7 & Regunathan (2008) \\
\hline F. indicus (domesticated G2) & 2.24 & 32.0 & Regunathan (2008) \\
\hline P. semisulcatus (wild) & 2.14 & 41.6 & Browdy et al. (1986) \\
\hline P. semisulcatus (pond-reared G1) & 1.98 & 38.9 & Browdy et al. (1986) \\
\hline L. stylirostris (wild) & 1.92 & 58.8 & Mendoza (1997) \\
\hline L. stylirostris (pond-reared G5) & 1.25 & 53.4 & Mendoza (1997) \\
\hline P. esculentus (wild) & 0.8 & 58.0 & Keys and Crocos (2006) \\
\hline P. esculentus (tank-reared G1) & 0.35 & 49.4 & Keys and Crocos (2006) \\
\hline P. esculentus (pond-reared G2) & 0.77 & 42.7 & Keys and Crocos (2006) \\
\hline F. paulensis (wild) & 1.99 & 54.9 & Cavalli et al. (1997) \\
\hline F. paulensis (pond-reared) & 3.58 & 21.6 & Cavalli et al. (1997) \\
\hline F. duorarum (wild) & 2.6 & 25.9 & Present study \\
\hline F. duorarum (tank-reared G2) & 1.7 & 19.6 & Present study \\
\hline
\end{tabular}

eggs per spawn, higher GSI, as well as high AG content in hemolymph and OV indicating a higher gonad development than domesticated ones. Furthermore, higher levels of AG in eggs of 1st spawn wild females compared to 1st spawn domesticated females also indicate a better transfer to eggs. This trend was followed in FA profile, mainly represented by DHA and sum of n-3. Eggs from wild females at their 1 st spawn had higher levels (10.9 and $18.4 \%$, respectively) as compared to their domesticated counterparts ( 8.8 and $16.0 \%$ ). Moreover, its levels strongly decreased in the 1 st to the 2 nd spawn order and could not be sufficient to maintain stable levels, although it must be explained by an important increase of eggs production in the 2nd spawn order and over time (Fig. 2), resulting in final lower mean levels as compared to their domesticated counterparts. High mean levels of HUFA such as ARA and EPA were found in HP and OV from wild females (Table 3), possible due to a better nutrition in wild prior to maturation phase. Deficit in these HUFA contributed to decrease on embryogenesis (Clarke et al., 1990) and vitellogenesis (Wouters et al., 2001c).

Cholesterol is an important cell constituent in crustaceans, and is a precursor of steroid and molt hormones (D'Abramo, 1997). However, crustacean cells cannot synthesize cholesterol or other sterols de novo and need it from the diet (Teshima, 1972). The low levels of AG observed in HP from 1st spawn wild females as compared to domesticated ones was also observed in cholesterol content; although these 
differences were not seen in other tissues. Cholesterol is also an important component of lipoproteins (i.e. vitellogenin) involved in AG transfer into OV (Kanazawa and Teshima, 1971), and therefore its low levels of cholesterol in HP could be explained by a higher cholesterol turnover related to vitellogenin synthesis and transport to OV.

Hemocyanin plays a key role in oxygen transport and protein reserves in hemolymph (Chen and Cheng, 1993) and also participates in shrimp immune response (Pascual et al., 2003). Its levels are affected by the molting process (Bursey and Lane, 1971, Cheng et al., 2002) and dietary protein levels (Rosas and Carrillo, 2006). In the present study, hemocyanin levels of wild females were lower than domesticated ones. Such result could be related to a high protein turnover in wild shrimp, which is also suggested by a lower protein content level in nauplii obtained from wild spawners as a result of high spawning activity.

\subsection{Multivariate analysis}

EOF multivariate analysis (Jeronimo, 2007) is a tool to detect simultaneous variation in biochemical variables which many times is not seen in univariate analysis. EOF performed in our study allowed to detect AG as variation pattern responsive in 1 st and 4 th spawn order for all tissues, with more than $85 \%$ of energy retention (Table 5 ). Such result was corroborated with biochemical analysis performed in a univariate way, where AG showed a key role on nutrient flux and spawning activity. A scheme of nutrient flux, EOF's MEV (mode 1) and biochemical status of 1st and 4th spawn domesticated and wild females is given in Fig. 4. AG was also detected as the most responsive of variation retention in both origins and tissues, including the general trend. Biochemical status was represented by a pyramid where as more open is the pyramid better the animal nutritional condition is. Both origins showed the same general trend. Such result concluded that some specific nutrients such as essential FA could be more responsive than the metabolite changes measured in this study. Optimum ratios of HUFA will enable broodstock diets to be improved and enhance the reproductive outcomes in penaeid species (Coman et al., 2011; Wouters et al., 2001c). Multivariate analysis applied to broodstock nutrition seemed to be a tool to clarify nutrient traceability, detecting simultaneous variations. Further research is encouraged on this field.

\section{Conclusion}

In the present study wild population of $F$. duorarum presented better reproductive performance as compared to domesticated ones. Multiple spawning was reflected in some biochemical variables such as AG and cholesterol content in HP, hemolymph and OV. Higher content of some nutrients such as DHA and sum of $n-3$ in the 1 st spawn order in domesticated females was related to a slow response to ablation whereas lower levels in wild populations was attributed to an accentuated response to eyestalk ablation, possible due to a better nutrition in wild prior to maturation phase. Additionally, wild females spawned more promptly, had a higher eggs production and a quickly gonad development as compared to domesticated ones.

Domestication of broodstock is common in shrimp industry to control production plan with successive generations (Coman et al., 2007). Our results and their practical implications should be taken in place for selecting $F$. duorarum broodstock origin in terms of reproductive performance and biochemical characteristics. However, domestication process using advanced generations (i.e. > G9) could be analyzed as it has shown advantages (Gitterle et al., 2005; Goyard et al., 2002; Wabete et al., 2006). On the other hand, nutritional problems in domesticated broodstock remain unresolved (Wouters et al., 2001a) and alternatives should be evaluated. The role of broodstock origin and nutritional history impacted on $F$. duorarum reproductive performance. Further research are encouraged to evaluate different food protocols and diets (i.e. dry pellets vs fresh food maturation diet and short-term vs long-term fresh food supplementation prior to ablation) aiming to improve $F$. duorarum outcomes.

\section{Acknowledgments}

The authors would like to thank Coordenação de Aperfeiçoamento de Pessoal de Nivel Superior-CAPES, Brazilian Ministry of Education (PhD grant number 4814061 provided to the primary author) and Consejo Nacional de Ciencia y Tecnología-CONACyT, México (grant 60824) for research support. The authors also would like to thank Santiago Capella, Manuel Valenzuela, Adriana Paredes, Gabriela Palomino and Gabriel Taboada for their contribution in this study. Advice and technical assistance on biochemical analysis from Ariadna Sanchez and Vianey Sosa are greatly appreciated. Thanks are also due to David A. Zaragoza Ortega for critical reading of the manuscript, and to anonymous referees for their valuable suggestions on this manuscript.

\section{References}

Aragón-Axomulco, H., Chiappa-Carrara, X., Soto, L., Cuzon, G., Arena, L., Maldonado, C. Cárdenas, R., Gaxiola, G., 2012. Seasonal variability in trypsin and $\alpha$-amylase activities caused by the molting cycle and feeding habits of juvenile pink shrimp Farfantepenaeus duorarum (Burkenroad, 1939). Journal of Crustacean Biology 32, 89-99.

Arcos, G.F., Ibarra, A.M., Vazquez-Boucard, C., Palacios, E., Racotta, I.S., 2003. Feasible predictive criteria for reproductive performance of white shrimp Litopenaeus vannamei: egg quality and female physiological condition. Aquaculture 228, 335-349.

Arcos, F.G., Racotta, I.S., Palacios, E., Ibarra, A.M., 2005a. Ovary development at the onset of gametogenesis in shrimp Litopenaeus (Penaeus) vannamei is genetically determined and correlated with reproductive traits at maturity. Marine Biology 148, 339-346.

Arcos, F.G., Palacios, E., Ibarra, A.M., Racotta, I.S., 2005b. Larval quality in relation to consecutive spawnings in white shrimp Litopenaeus vannamei Boone. Aquaculture Research 36, 890-897.

Arreguin-Sanchez, F., Zetina-Rejón, M., Ramírez-Rodríguez, M., 2008. Exploring ecosystem-based harvesting strategies to recover the collapsed pink shrimp (Farfantepenaeus duorarum) fishery in the southern Gulf of Mexico. Ecological Modelling 214, 83-94.

Arreguín-Sánchez, F., Schultz-Ruíz, L.E., Gracia, A., Sánchez y, J.A., Alarcón, T., 1997. Las pesquerías de camarón de altamar, explotación, dinámica y evaluación. In: FloresHernández, D., Sánchez-Gil, P., Seijo y, J.C., Arreguín-Sánchez, F. (Eds.), Análisis y diagnóstico de los recursos pesqueros críticos del Golfo de Méxco: Univ. Autón. Campeche, EPOMEX Serie Científico, 7, pp. 145-172. México.

Bradford, M.M., 1976. A rapid and sensitive method for the quantification of microgram quantities of protein utilizing the principle of protein-dye binding. Annals of Biochemistry 72, 248.

Bray, W.A., Lawrence, A.L., 1992. Reproduction of Penaeus species in captivity. In: Fast, A.W., Lester, L.J. (Eds.), Marine Shrimp Culture: Principles and Practices. Elsevier Science Publishers, Amsterdam, The Netherlands, pp. 93-170.

Browdy, C.L., Samocha, T.M., 1985. The effect of eyestalk ablation on spawning, molting and mating of Penaeus semisulcatus de Haan. Aquaculture 49, 19-29.

Browdy, C.L., Hadani, A., Samocha, T.M., Loya, Y., 1986. The reproductive performance of wild and pond-reared Penaeus semisulcatus de Haan. Aquaculture 59, 251-258.

Browdy, C.L., 1998. Recent developments in penaeid broodstock and seed production technologies: improving the outlook for superior captive stocks. Aquaculture $164,3-21$

Bursey, C.R., Lane, C.E., 1971. Ionic and protein concentration changes during the molt cycle of Penaeus duorarum. Comparative Biochemistry and Physiology 40, 155-162.

Cahu, C., Guillaume, J.C., Stéphan, G., Chim, L., 1994. Influence of phospholipid and highly unsaturated fatty acids on spawning rate and egg and tissue composition in Penaeus vannamei fed semi-purified diets. Aquaculture 126, 159-170.

Cavalli, R.O., Scardua, M.P., Wasielesky, W.J., 1997. Reproductive performance of different sized wild and pond-reared Penaeus paulensis females. Journal of World Aquaculture Society 28, 260-267.

Chen, J.C., Cheng, S.Y., 1993. Studies in haemocyanin and haemolymph protein levels of Penaeus japonicus based on sex, size and moulting cycle. Comparative Biochemistry and Physiology. B 106, 293-296.

Cheng, W., Liu, C.H., Yan, D.F., Chen, J.C., 2002. Haemolymph oxyhemocyanin, protein, osmolality, and electrolyte levels of whiteleg shrimp Litopenaeus vannamei in relation to size and molt stage. Aquaculture 211, 325-339.

Clarke, A., Brown, J.H., Holmes, L.J., 1990. The biochemical composition of eggs from Macrobrachium rosenbergii in relation to embryonic development. Comparative Biochemistry and Physiology 96, 505-511.

Coman, G.J., Crocos, P.J., 2003. Effect of age on the consecutive spawning of ablated Penaeus semisulcatus broodstock. Aquaculture 219, 445-456.

Coman, G.J., Arnold, S.J., Peixoto, S., Coman, F.E., Crocos, P.J., Preston, N.P., 2006. Reproductive performance of reciprocally crossed wild-caught and tank reared Penaeus monodon broodstock. Aquaculture 252, 372-384.

Coman, G.J., Arnold, S.J., Callaghan, T.R., Preston, N.P., 2007. Effect of two maturation diet combinations on reproductive performance of domesticated Penaeus monodon. Aquaculture 263, 75-83. 
Coman, G.J., Arnold, S.J., Barclay, M., Smith, D.M., 2011. Effect of arachidonic acid supplementation on reproductive performance of tank-domesticated Penaeus monodon. Aquaculture Nutrition 17, 141-151.

Cripe, G., 1994. Induction of maturation and spawning of pink shrimp, Penaeus duorarum, by changing water temperature, and survival and growth of young. Aquaculture $128,255-260$.

D'Abramo, L.R., 1997. Triacylglycerol and fatty acids. In: D'Abramo, L.R., Conklin, D.E., Akiyama, D.M. (Eds.), Crustacean Nutrition. : World Aquaculture Society, 6. Baton Rouge, LA, pp. 71-84.

Emmerson, W.D., 1980. Induced maturation of prawn Penaeus indicus. Marine Ecology Progress Series 2, 121-131.

Folch, J., Lees, M., Sloane-Stanley, G.H., 1957. A simple method for the isolation and purification of total lipids from animal tissues. Journal of Biological Chemistry 226, 497-509.

Gitterle, T., Salte, R., Gjerde, B., Cock, J., Johansen, H., Salazar, M., Lozano, C., Rye, M. 2005. Genetic (co) variation in resistance to White Spot Syndrome Virus (WSSV) and harvest weight in Penaeus (Litopenaeus) vannamei. Aquaculture 246, 139-149.

Gracia, A., 1995. Impact of artisanal fishery on production of the pink shrimp Penaeus Farfantepenaeus duorarum Burkenroad, 1939. Ciencias Marina 21, 343-359.

Gracia, A., 1997. Pesquería artesanal de camarón. In: Flores-Hernández, D., Sánchez-Gil, P., Seijo y, J.C., Arreguín-Sánchez, F. (Eds.), Análisis y diagnóstico de los recursos pesqueros críticos del Golfo de, México: Univ. Autón. Campeche, EPOMEX, Serie Científico, 7, pp. 173-184. México.

Gomez-Valdes, J., Jeronimo, G., 2009. Upper mixed layer temperature and salinity variability in the tropical boundary of the California Current, 1997-2007. J. Geophys. Res-Oceans 114, C03012.

Goyard, E., Patrois, J., Peignon, J., Vanaa, V., Dufour, R., Viallon, J., Bedier, E., 2002. Selection for better growth of Penaeus stylirostris in Tahiti and New Caledonia. Aquaculture 204, 461-468.

Gullian, M., Aramburu, C., Sanders, B., Lope, R., 2010. Viability of culturing pink shrimp Farfantepenaeus duorarum in low-salinity groundwater from the Yucatán Peninsula (SE, México). Aquaculture 302, 202-207.

Hansford, S.W., Marsden, G.E., 1995. Temporal variation in egg and larval productivity of eyestalk ablated spawners of the prawn Penaeus monodon from Cook Bay, Australia. Journal of World Aquaculture Society 26, 396-400.

Harrison, K.E., 1990. The role of nutrition in maturation, reproduction and embryonic development of decapod crustaceans: a review. Journal of Shellfish Research 9, $1-28$.

Hoa, N.D., Wouters, R., Wille, M., Thanh, V., Dong, T.K., Hao, N.V., Sorgeloos, P., 2009. A fresh-food maturation diet with an adequate HUFA composition for broodstock nutrition studies in black tiger shrimp Penaeus monodon (Fabricius, 1798). Aquaculture 297, 116-121.

Ibarra, A., Ramírez, J.L., Racotta, I.S., Palacios, E., Magallon, F., 1997. Performance comparison of eggs and nauplii for spawners from a second generation domesticated and wild shrimp of Penaeus vannamei. In: Alston, D.E., Green, B.W., Clifford, H.C. (Eds.), IV Symposium on Aquaculture in Central America, 22-24 April, Tegucigalpa, Honduras, WAS-ANDAH, pp. 159-160.

Ibarra, A.M., Racotta, I.S., Arcos, F.G., Palacios, E., 2007. Progress on the genetics of reproductive performance in penaeid shrimp. Aquaculture 268, 23-43.

Jeronimo, G., 2007. Variabilidad termohalina de la capa superior del océano en la región sur de la corriente de california. PhD tesis, CICESE, Ensenada, Mexico.

Keys, S.J., Crocos, P.J., 2006. Domestication, growth and reproductive performance of wild, pond and tank-reared brown tiger shrimp Penaeus esculentus. Aquaculture 257, 232-240

Kanazawa, A., Teshima, S., 1971. In vivo conversion of cholesterol to steroid hormones in the spring lobster, Palinurus juponicus. Bulletin of the Japanese Society of Scientific Fisheries 37, 891-897.

Lytle, J.S., Lytle, T.F., Ogle, J.T., 1990. Polyunsaturated fatty acid profiles as a comparative tool in assessing maturation diets of Penaeus vannamei. Aquaculture 89, 287-299.

López-Téllez, N., Hernández-Rodríguez, J., Ramírez-Ligonio, H., Seca-Escalante, J., 2000. Crecimiento del camarón rosado Farfantepenaeus duorarum en estanques rústicos. Ciencia Pesquera 14, 29-32.

Marsden, G., McGuren, J.M., Sarac, H.Z., Neill, A.R., Brock, I.J., Palmer, C.L., 1992. Nutritional composition of some natural marine feeds used in prawn maturation. In: Allan, G.L., Dall, W. (Eds.), Proc. Aquaculture Nutrition Workshop, Salamander Bay, April 15-17, 1991. NSW Fisheries, Brackish Water Fish Culture Research Station, Salamander Bay, Australia, pp. 82-86

Marsden, G.E., McGuren, J.J., Hansford, S.W., Burke, M.J., 1997. A moist artificial diet for prawn broodstock: its effect on the variable reproductive performance of wild caught Penaeus monodon. Aquaculture 149, 145-156.

Marsden, G.E., Mather, P., Richardson, N., 2007. Captivity, ablation and starvation of the prawn Penaeus monodon affects protein and lipid content in ovary and hepatopancreas tissues. Aquaculture 271, 507-515.

Menasveta, P., Piyatiratitivorakul, S., Rungsurpa, S., Moree, N., Fast, A.W., 1993. Gonadal maturation and reproductive performance of giant prawn (Penaeus monodon Fabricius) from the Andaman Sea and pond-reared sources in Thailand. Aquaculture 116,191-198.

Mendoza, R., 1997. Penaeus stylirostris nauplii production from wild, cultivated and mixed populations. Journal of Applied Aquaculture 7, 41-50.

Millamena, O.M., Pascual, F.P., 1990. Tissue lipid content and fatty acid composition of Penaeus monodon Fabricius broodstock from the wild. Journal of World Aquaculture Society $21,116-121$.

Mourente, G., Rodríguez, A., 1997. Effects of salinity and dietary DHA (22:6n3) content on lipid composition and performance of Penaeus kerthurus postlarvae. Marine Biology 128, 289-298.
Nakayama, C.L. Peixoto, S.,Bianchini, A, Robaldo, R.B., Cavalli, R.O, 2008. Performance of Farfantepenaeus paulensis (Pérez-Farfante, 1967) broodstock in tanks with sand and hard substrate. Aquaculture Research 39, 398-400.

Palacios, E., Ibarra, A.M., Ramirez, J.R., Portillo, G., Racotta, I.L., 1998. Biochemical composition of eggs and nauplii on white pacific shrimp Penaeus vannamei (Boone) in relation to the physiological condition of spawners in the commercial hatchery. Aquaculture Research 29, 183-189.

Palacios, E., Racotta, I.S., APSA, 1999a. Spawning frequency analysis of wild and pondreared shrimp Penaeus vannamei broodstock under large-scale hatchery conditions. Journal of World Aquaculture Society 30, 180-191.

Palacios, E., Perez-Rostro, C.I., Ramirez, J.L., Ibarra, A.M., Racotta, I.S., 1999b. Reproductive exhaustion in shrimp (Penaeus vannamei) reflected in larval biochemical composition, survival and growth. Aquaculture 171, 309-321.

Palacios, E., Ibarra, A.M., Racotta, I.S., 2000. Tissue biochemical composition in relation to multiple spawning in wild and pond-reared Penaeus vannamei broodstock. Aquaculture 185, 353-371.

Palacios, E., Racotta, I.S., 2003. Effect of number of spawns on the resulting spawn quality of 1-year-old pond-reared Penaeus vannamei (Boone) broodstock. Aquaculture Research 34, 427-435.

Pascual, C., Gaxiola, G., Rosas, C., 2003. Blood metabolites and hemocyanin of the white shrimp Litopenaeus vannamei: the effect of culture conditions and a comparison with other crustacean species. Marine Biology 142, 735-745.

Pérez-Farfante, I., 1969. Western Atlantic shrimps of the genus Penaeus. Fishery Bulletin 67, 461-591.

Peixoto, S., Cavalli, R.O., Wasielesky, W., D'Incao, F., Krummenauer, D., Milach, A., 2004. Effects of age and size on reproductive performance of captive Farfantepenaeus paulensis broodstock. Aquaculture 238, 173-182.

Peixoto, S., Wasielesky, W., Martino, R., Milach, A., Soares, R., Cavalli, R.O., 2008. Comparison of reproductive output, offspring quality, ovarian histology and fatty acid composition between similarly-sized wild and domesticated Farfantepenaeus paulensis. Aquaculture 285, 201-206.

Peixoto, S., Wasielesky, W., Cavalli, R.O., 2011. Broodstock maturation and reproduction of the indigenous pink shrimp Farfantepenaeus paulensis in Brazil: an updated review on research and development. Aquaculture 315, 9-15.

Primavera, J.H., Posadas, R.A., 1981. Studies on the egg quality of Penaeus monodon Fabricius, based on morphology and hatching rates. Aquaculture 22, 269-277.

Racotta, I.S., Palacios, E., Ibarra, A.M., 2003. Shrimp larval quality in relation to broodstock condition. Aquaculture 227, 107-130.

Racotta, I.S., Palacios, E., Hernández-Herrera, R., Bonilla, A., Ramirez, J.L., 2004. Criteria for assesing larval and postlarval quality in white pacific shrimp (Litopenaeus vannamei, Boone, 1931). Aquaculture 233, 181-195.

Regunathan, C., 2008. Variation in reproductive performance and egg quality between wild and pond-reared indian white shrimp, Fenneropenaeus indicus, broodstock. Journal of Applied Aquaculture 20, 1-17.

Rosas, C., Carrillo, O., 2006. Principales rutas metabólicas. Utilización de la energía. In: Rosas, C., Carrillo, O., Wilson, R., Andreatta, E. (Eds.), Estado Actual y Perspectivas de la Nutrición de los Camarones Peneidos Cultivados en Iberoamérica. CYTED, México, pp. 61-88.

Rosas, C., Cooper, E.L., Pascual, C., Brito, R., Gelabert, R., Moreno, T., Sánchez, A., 2007 Physiological and immunological conditions of the wild populations of Farfantepenaeus duorarum from the Campeche Sound (Crustacea, Penaeidae). Marine Biology $152,929-938$

Samocha, T.M., Gandy, R.L., Morris, T.C., Patnaik, S., Kim, J.S., Davis, A.D., Richardson, J.R Browdy, C.L., 2008. Development of viral pathogen free broodstock populations of the Atlantic pink shrimp Farfantepenaeus duorarum and the Atlantic white shrimp Litopenaeus setiferus. Abstract of Aquaculture America 2008, World Aquaculture Society Meeting, Florida, p. 399.

Schwamborn, R., Criales, M.M., 2000. Feeding strategy and daily diet of juvenile pink shrimp (Farfantepenaeus duorarum) in a South Florida seagrass bed. Marine Biology 137, 139-147.

Shiau, S., Wu, M., 2003. Dietary vitamin B6 requirement of grass shrimp, Penaeus monodon. Aquaculture 225, 397-404.

Soares, R., Peixoto, S., Wasielesky Jr., W., D'Incao, F., 2005. Feeding rhythms and diet of Farfantepenaeus paulensis under pen culture in Patos Lagoon estuary, Brazil. Journal of Experimental Marine Biology and Ecology 322, 167-176.

Soares, R., Peixoto, S., Bemvenuti, C., Wasielesky, W., D'Incao, F., Murcia, N., Suita, S. 2004. Composition and abundance of invertebrate benthic fauna in Farfantepenaeus paulensis culture pens (Patos Lagoon estuary, Southern Brazil). Aquaculture 239, 121-199.

Sokal, R., Rohlf, J., 1995. Biometry, the principles and practice of statistics in biological research. W H Freeman, New York

Tahara, D., Yano, I., 2004. Maturation-related variations in prostaglandins and fatty acid content of ovary in the kuruma prawn (Marsupenaeus japonicus). Comparative Biochemistry and Physiology. A 137, 631-637.

Teshima, S., 1972. Sterol metabolism. Memoirs of the Faculty of Fisheries, 21. Kagoshima University, pp. 69-147.

Teshima, S.I., Kanazawa, A., 1983. Variation in lipid composition during the ovarian maturation of the prawn. Bulletin of the Japanese Society of Scientific Fisheries 49, 957-962.

Teshima, S.I., Kanazawa, A., Kushio, S., Horinouchi, K., 1988. Lipid metabolism in destalked prawn Penaeus japonicus: induced maturation and accumulation of lipids in the ovaries. Nippon Suisan Gakkaishi 54, 1115-1122.

Tseng, D.Y., Chen, Y.N., Kou, G.H., Lo, C.F., Kuo, C.M., 2001. Hepatopancreas is the extraovarian site of vitellogenin synthesis in black tiger shrimp, Penaeus monodon. Comparative Biochemistry and Physiology. Part A, Molecular \& Integrative Physiology 129 (4), 909-917. 
Vazquez Boucard, C.G., Patrois, J., Ceccaldi, H.J., 2004. Exhaustion of lipid reserves in the hepatopancreas of Fenneropenaeus indicus broodstock in relation to successive spawnings. Aquaculture 236, 523-537.

Vargas-Albores, F., Guzmán, M.A., Ochoa, J.L., 1993. An anticoagulant solution for haemolymph collection and prophenoloxidase studies of penaeid shrimp (Penaeus californiensis). Comparative Biochemistry and Physiology. A 160, 299-303.

Von Storch, H., Zwiers, F.W., 2001. Statistical Analysis in Climate Research. Cambridge University Press, Cambridge, UK.

Wabete, N., Chim, L., Pham, D., Lemaire, P., Massabuau, J.C., 2006. A soft technology to improve survival and reproductive performance of Litopenaeus stylirostris by counterbalancing physiological disturbances associated with handling stress. Aquaculture 260, 181-193.

Wouters, R., Gomez, L., Lavens, P., Calderon, J., 1999. Feeding enriched Artemia biomass to Penaeus vannamei broodstock: its effect on reproductive performance and larval quality. Journal of Shellfish Research 18, 651-656.
Wouters, R., Lavens, P., Nieto, J., Sorgeloos, P., 2001a. Penaeid shrimp broodstock nutrition: an updated review on research and development. Aquaculture 202, 1-21.

Wouters, R., Molina, C., Lavens, P., Calderón, J., 2001b. Lipid composition and vitamin content of wild female Litopenaeus vannamei in different stages of sexual maturation. Aquaculture 198, 307-323.

Wouters, R., Piguave, X., Bastidas, L., Calderón, J., Sorgeloos, P., 2001c. Ovarian maturation and haemolymphatic vitellogenin concentration of Pacific white shrimp Litopenaeus vannamei (Boone) fed increasing levels of total dietary lipids and HUFA. Aquaculture Research 32, 573-582.

Xu, X.L., Ji, W., Castell, J.D., O'Dor, R.K., 1994. Essential fatty acid requirements of the Chinese prawn, Penaeus chinensis. Aquaculture 127, 29-40.

Zar, J.H., 1984. Biostatistical Analysis, second ed. Prentice Hall, Englewood Cliffs, NJ. 